
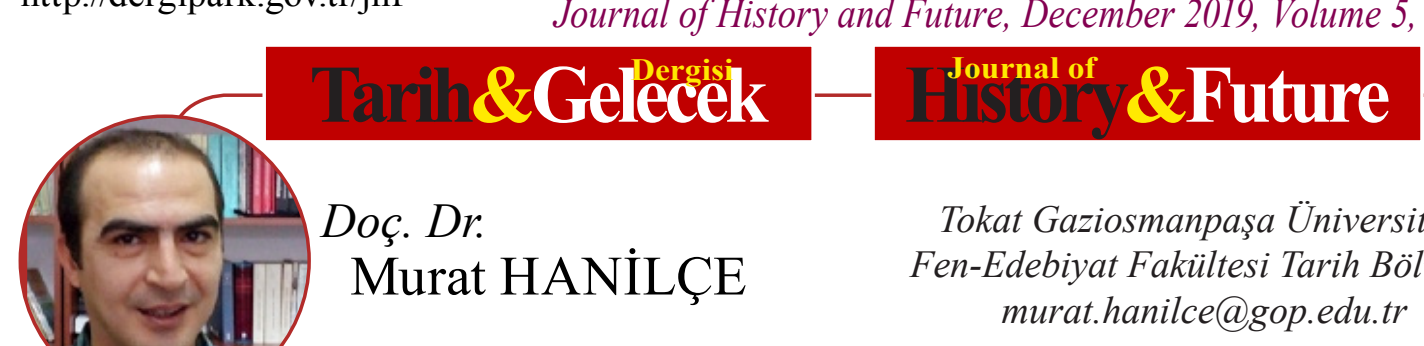

Tokat Gaziosmanpaşa Üniversitesi Fen-Edebiyat Fakültesi Tarih Bölümü, murat.hanilce@gop.edu.tr

ORCiD: https://orcid.org/ 0000-0003-0587-9336

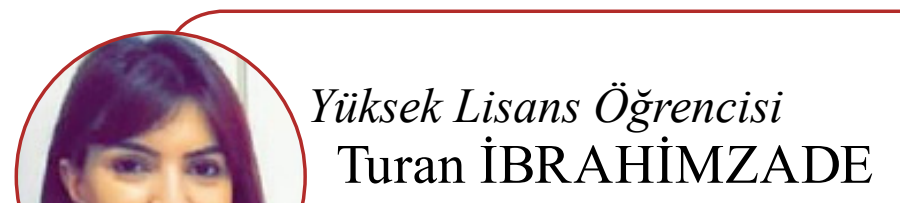

Tokat Gaziosmanpaşa Üniversitesi Sosyal Bilimler Enstitüsü Tarih Anabilim Dall, turan.ibrahimzade4417@gop.edu.tr

ORCiD: https://orcid.org/0000-0002-8784-1253

\begin{tabular}{|c|c|c|}
\hline Eser Gecmisi / Article Past: & $\begin{array}{l}\text { Başvuruda bulundu. } \\
\text { Applied } \\
13 / 10 / 2019\end{array}$ & $\begin{array}{c}\text { Kabul edildi. } \\
\text { Accepted } \\
05 / 11 / 2019\end{array}$ \\
\hline
\end{tabular}

\title{
Çariçe Katerina'nın Rus Kadın Eğitimine Sağladığı Bir Katkı -Smolniy Enstitüsü (1764-1919)-
}

\author{
A Contribution of Tsarist Catherine II to Russian Women's \\ Education -Institute of Smolny (1764-1919)-
}

\section{Öz}

18. yüzyılda Aydınlanma Çağı boyunca fikir, sanat ve bilim insanları gibi bazı hükümdarlar da çağın getirdiğgi ilkeleri benimsemiştir. Hatta Avusturya Imparatoru II. Joseph, Prusya Kralı Büyük Frederick bunlar içerisinde başı çekmiştir. Aralarında İkinci Katerina'nın da bulunduğu bu hükümdarların "Aydın Despotizmi” adı da verilen anlayışları ülkelerinde birçok yeni gelişmenin önünü açmış̧ır. Bu aydın despotlar bir taraftan aydınları destekleyerek yeniliklere kapı aralarken bir yandan da demir yumrukla ülkelerini idare etmeyi bilmiştir. İkinci Katerina, gerçekleştirmiş olduğu diğer reformların yanı sıra, Rusya'da kadın eğitimine yönelik yapmış olduğu çalışmalar ile dünyada kadın eğitiminin öncü simalarından birisi olmayı başarmıştır.

Bu çalışmada İkinci Katerina'nın Rusya'daki klz çocukların eğitimi için 1764 'te açtı̆̆g "Soylu Genç Klzlar Enstitüsü", diğer adı ile "Smolniy Enstitüsü", ele alınmıştır. Çalışmada ağırlıklı olarak Rusça ve kismen Türkçe kaynaklardan yararlanılmıştır. İlk olarak Birinci Petro'dan Íkinci Katerina'ya kadar geçen süre zarfinda Rusya'nın eğitim sürecinin geçirmiş olduğu evre ele alınmış; ardından da Smolniy Entitüsü değerlendirilmiştir. Böylece Rusya'da açılan bu kadın eğitim kurumunun o tarihlerde yerine getirdiği misyon ortaya konulmaya çalışılmıştır. Günümüzde zaman zaman Türkiye'de de tartışlan kadınların kendilerine özgü eğitim kurumlarında eğitim alması fikrinin ortaya çıkma nedenleri Rusya özelinde aktarılmıştır.

Anahtar Kelimeler: Smolniy, kadın, eğitim, Katerina, Rusya.

ATIF: HANİLÇE Murat, İBRAHİMZADE Turan, "Çariçe Katerina'nın Rus Kadın Eğitimine Sağladığ1 Bir Katk1 -Smolniy Enstitüsü (1764-1919)-" Tarih ve Gelecek Dergisi, 5/3 (Aralık-2019), s. (503-528)

CITE: HANILÇE Murat, İBRAHIMZADE Turan, "A Contribution of Tsarist Catherine II to Russian Women's Education -Institute of Smolny (1764-1919)-" Journal of History and Future, 5/3 (December- 2019), pp. (503-528) 


\begin{abstract}
Throughout the Age of Enlightenment in the $18^{\text {th }}$ century, some rulers as well as intellectuals, artistst and scientists adopted some of the principles of the age. The Austrian Emperor Joseph II, the King of Prussia Frederick the Great, even took the lead. The understanding of these rulers, including the Great Catherine, called "Despotism of the Enlightenment" paved the way for many new developments in their countries. These enlightened despots, on the one hand, supported the intellectuals and opened the door to innovations, while at the same time they managed to manage their countries with iron fists. In addition to the other reforms she carried out, Catherine II succeeded in becoming one of the pioneers of women's education in the world with her studies on women's education in Russia.

In this study, the "The Institute of Noble Young Girls" also called "Institute of Smolny" which was opened by Catherine II in 1764 for the education of girls in Russia, is discussed. In this study, mainly Russian and partly Turkish sources were used. Firstly, the phase of Russia's education process from the Petro I to the Catherine II was discussed; and then Institute of Smolny was evaluated. Thus, it was tried to put forward the mission of this women's education institution which was opened in Russia at that time. Today from time to time discussed also in Turkey, the causes of emergence of the idea of women receiving education in their own educational institutions were transferred in the example of Russia.
\end{abstract}

Keywords: Smolny, women, education, Catherine, Russia

\title{
Giriş
}

\section{Katerina'ya Kadar Rusya'da Eğitimin Modernleşmesine Bir Bakış}

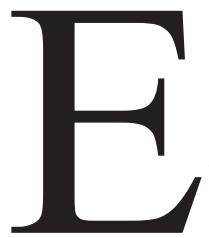

ğitim, Aydınlanma Çağı düşünürlerinin üzerinde kafa yorduğu önemli bir alan olmuştur. Bu çağın düşünürlerinin neredeyse tamamı yeni bir eğitim sistemine geçilmesi konusunda fikir birliği içerisinde hareket etmişlerdir. Aydınlar, yeni eğitim sistemi yardımıyla içerisinde yaşadıkları ülkelerin vatandaşlarının hem kültür hem de eğitim seviyelerinin artacağına inanmışlardır. Yeni eğitim sisteminin işler hale gelmesinde aydınların fikirleri yanında daha sonra aydın despotlar olarak anılacak Avusturya İmparatoru İkinci Joseph, Prusya Kralı Büyük Frederick ve Rus Çariçesi İkinci Katerina ${ }^{1}$ gibi hükümdarların desteği de dikkat çekmiştir. Bu çağ içerisinde gerçekleştirilen

1 Soylu bir geçmişi olan Alman asıllı İkinci Katerina, Anhalt-Zerbst prensi Christian August'un (16901747) ilk kızı olarak dünyaya gelmiştir. Küçük yaştan başlayarak iyi bir eğitim alan ve tam adı Yekatarina Alexeyevna olan Katerina 1744'te Rusya'ya gitmiştir. 1762'de başarılı bir darbe sonrasında Rus tahtını ele geçirmeyi başarmıştır. Katerina, eğitimini Avrupa'da aldığı için çoğu Fransızca yazılmış birçok roman, oyun ve şiiri okumuştur. Diderot, Voltaire ve Montesquieu'nun birçok başyapıtını gözden geçirmiştir. Yabancı dildeki kitapların Rusçaya çevirilmesi için bir cemiyet kurmuş; bu cemiyet 1782'de kurulan Rus Akademisi'nin altyapısını teşkil etmiştir. Müzik, bahçe peyzajı ve daha birçok konuda girişimleri olan Katerina’nın bütün çabalarının ortak amacı Rusya'da milliyetçi hislerin geliştirilmesi ve Rus halkında Rus milleti olmaya yönelik duyguların çoğaltılmasıydı. Bu da aydınlanma çağının genel eğilimlerinin bir sonucuydu. İkinci Katerina Rusya'da yasamadan idareye birçok yenilikçi reformun altına imzasını atmıştır. Onun zamanında Ruslar dış politikada oldukça başarılı olmuş; Lehistan'ı Prusya ve Avusturya ile paylaşmış; 1768-1774 arasında Osmanlı ile olan savaşı kazanmış ve Kırım'da üstünlüğü ele geçirmiştir. Böylelikle İkinci Katerina yaptıklarıyla Birinci Petro'dan itibaren Rusya'nın yakalamış olduğu büyüme ve gelişme sürecini olgunlaştıran bir lider olmayı başarmıştır. Büyük Katerina ve yaşamı hakkında detaylı bilgi için bk. Fuat Uçar, "II. Katerina (17621796)", Uzman Araştırmacı Eğitim Programı Makaleler-I içinde, ed. Turgay Anar (İstanbul: İstanbul Bilimler Akademisi Vakfı Yayın, 2017): 53-80; Akdes Nimet Kurat, Rusya Tarihi Başlangıçtan 1917'ye Kadar (Ankara: Türk Tarih Kurumu Yayını, 1987), 281-296; Serhat Kuzucu, "II. Katerina Dönemi Osmanl1-Rus İlişkilerinde Kırım”, Türk Dünyası Araştırmaları, S. 185 (2010): 107-118; Mahir Aslan, “1783 Kırım’ın Rusya'ya İlhakı Sürecinde İkinci Katerina’nın Yunan Projesi ve Önemi”, Türk Dünyası Araştırmaları, S. 213 (2014): 221-230; Kadir Şıhverdiyev, "II. Katherina (1729-1796) Döneminde Rusya Müslümanları" (Yüksek Lisans Tezi, Erciyes: Üniversitesi Sosyal Bilimler Enstitüsü, 2006); Mehmet Saray, Türk-Rus Münasebetleri’nin Bir Analizi (İstanbul: MEB Yayını,1998), 75-107. 
reformlar Rus toplumunu yakından ilgilendirmiş ve Rusya'nın gelecek yıllarını önemli ölçüde etkilemiştir. Söz konusu zaman diliminde Rusya'da reformların hayata geçmesinde rol oynayan başlıca unsur Rusya'nın o dönemlerde oldukça güçlü bir devlet yapısına erişmesidir. Zira, 1600'lerin ikinci yarısında Rusya; Avrupa ve Asya’nın kesiştiği coğrafyada büyük bir güç merkezi, başka bir deyişle imparatorluk, haline gelmiştir. Rusya'da eğitim reformu 7 Eylül 1782 tarihinde İkinci Katerina'nın yayımlamış olduğu buyruk doğrultusunda yeni bir sürece girmiştir. Rusya'da, aynı dönemde birçok alanda olduğu gibi, eğitim alanındaki reformları zirveye ulaştıran Çariçe İkinci Katerina olmuştur².

Şunu açıkça belirtmek gerekir ki Rus çarlarının modern eğitim sistemine olan ilgisinin İkinci Katerina öncesine dayanan bir arka planı vardır. Örneğin, henüz on beş yaşında tahta çıkan ve altı sene boyunca Rusya'yı yöneten, Birinci (Büyük) Petro’nun üvey kardeşi, Fyodor Aleksiyeviç Romanov $^{3}$, küçük yaşına rağmen, Rusya'da yüksek derecede okulları kurma konusunda öncü ve nadir isimlerden birisi olmuştur. Onun verdiği talimatlarla Slavyan-Grek-Latin Akademisi 'nin açılış çalışmalarına hız verilmiştir. Ne var ki Rus yükseköğreniminin bu öncü kuruluşunun açılışı, onun ölümünden sonra, ancak 1685 yılında gerçekleştirilebilmiştir. Fyodor Aleksiyeviç’in, hayatının son yıllarına rastlayan bu yüksekokul veya akademi kurma projesi daha özgür bir eğitim anlayış1 içermesi bakımdan kendisinden önceki Rus eğitim hamlelerinden ayrılmaktadır. Bu projeyi farklı kılan özelliklerden birisi de Rus topraklarında yaşayanların devlet hazinesi desteğiyle okutulması; başka bir deyişle yükseköğrenimi devletin halkına ücretsiz bir biçimde sunması imkânı getirecek olmasıydı. Yalnız bu örnek bile, eğitim için ortaya atılan fikirler ve projelerin aslında İkinci Katerina'nın yönetiminden çok önce Rusya'da kendine bir yer edindiğini ortaya koymaktadır. $\mathrm{Bu}$ haliyle, İkinci Katerina Rus tahtına oturduğu zaman öncüllerinin hedeflerini korumuş ve bu hedeflere yenilerini katarak Rus reformlarının ve Rus yükseköğrenim sisteminin gelişmesine dikkate değer katkılarda bulunmuştur 5 .

2 В. И. Моряков, “Екатерина I1 И Русские Просветители О Воспитании «Истинного Сына Отечества»”, Екатерина Великая: Эпоха Российской Истории (Санкт-Петербург: Спб Нц, 1996), 81. [V. İ. Moryakov, “II. Katerina ve Rus Eğitim Aydınları-Gerçek Anavatan Evladı”, Rus Tarihinde Büyük Katerina Devri Uluslararası Sempozyumu Bildirileri Kitabı içinde, (St. Petersburg: St. Petersburg Bilim Merkezi Yayını, 1996), 81.]

3 Üçüncü Fyodor Alekseyeviç Romanov 9 Haziran 1661'de Rusya'da Romanovlar hanedanının bir bireyi olarak dünyaya gelmiş ve 1676 senesinde Rus çarı olmuştur. Tahta çıktığı günden itibaren kendisinden daha sonra tahta çıkacak olan kardeşi Birinci Petro’nun başlattığı reformların alt yapısını hazırlamıştır. İlk olarak vergi reformunu başlatmış; düzenli bir ordu kurmuş ve bütün soyluların alaylarda hizmet etmesini zorunlu hale getirmiştir. Onun yönetiminde Moskova’da bir matbaa açılmış, kimsesiz çocuklar için yaşam alanı sağlanmıştır. Üçüncü Fyodor 7 Mayıs 1682 tarihinde ölmüştür. Л. М. Марцева, “Из Истории Государства Российского. Династия Романовых Справочно-Хронологический Материал По Истории России", Национальные Приоритеты России 3(25), (2017): 5. [L. M. Martseva, "Rus Devleti’nin Tarihinden: Rus Tarihine Göre Romanov Hanedanlığının Kronolojisi”, Rusya'nın Geleneksel Portreleri Dergisi 3 (25) (2017): 5.

4 Slavyan-Yunan-Latin Akademisi, 1687 senesinde Moskova'daki Zaikonospassky ya da diğer adıyla Kutsal Mandylion Manastırı'nda açılmış Rusya'nın ilk akademisidir. İlk kurulduğunda Grek Dili, 1701 senesinde Slavyan Dili; 1775 senesinde ise Slavyan-Grek-Latin Akademisi olarak anılmıştır. Akademiye her yaştan ve her tabakadan öğrenci alınmış, bu öğrenciler kiliselerde ve okullarda çalışabilecek seviyede hazırlanmıştır. Öğrencilere felsefe, din, Latince, Grekçe, çeşitli yabancı diller, fizik, dilbilgisi ve edebiyat gibi dersler verilmiştir. Akademi 1814 senesinde Moskova İlahiyat Akademisi'ne dönüştürülmüş ve böylece eski vasfını yitirmiştir. Н. К. Гуркина, История Образования $B$ России ( $X-X X$ Века) (СПБ: СПБГУАП, 2001), 9. [N. K. Gurkina, Rusya’nın $X-X X$. Yüzyıl Eğitim Tarihi, (St. Petersburg: St. Petersburg Üniversitesi Havacılık Araçları Yayını, 2001), 9.]

5 С. М. Соловьев, История России С Древнейших Времен: В 29 Т. (Москва: Директ-Медиа, 2016), 


\section{Birinci Petro Zamanında Rus Eğitim Sisteminde Önemli Gelişmeler}

Birinci Petro Rusya'da "Büyük/Yüce" imparator olarak tarihe geçmiş ve Rusya için oldukça büyük adımlar atmıştır. Çar 9 Haziran 1672 senesinde Romanovlar hanedanının bir üyesi olarak dünyaya gelmiştir. 1682 senesinde tahta geçmiş ve 8 Şubat 1725'te ölene kadar tahtta kalmay1 başarmıştır. Rus modernleşmesi için çeşitli alanlarda reformlar başlatmış ve böylece ülkesinin gelişimine büyük katkılar sağlamıştır. Yaptığı reformlar sonucunda Rusya'nın ticaret hacmini arttırmış, ülkesinde toprak mülkiyetini düzenlemiş ve Rusya'nın üretim hacmini yükseltmiş, milli orduyu ve donanmayı kurmuştur. Rusya'yı dışa açmış ve Avrupa ile tanıştırmıştır. Rusya'nın kaderini büyük ölçüde değiştirmiştir ${ }^{6}$.

Birinci (Büyük) Petro'nun çarlığı sırasında Rusya'da birçok eğitim kurumu açılmıştır. Petro ve danışmanları ülkeyi çeşitli reformlarla modern hale getirmeye çalışmışlardır. O, Rus tahtında oturduğu süre zarfında eğitime dikkate değer katkılarda bulunmuştur. Örneğin, 18. yüzyıla girerken Rusya'da kamu kuruluşları haline gelen okullar görmek pek mümkün değildi. Ancak onun yaptığ1 reformlar sayesinde ülkede hem üst hem de alt sınıftan insanlara hitap eden birçok okul açılmış ve bunlar kamu kuruluşu halinde örgütlenmiştir. Böylece Birinci Petro’nun çarlığı döneminde Rusya'da çeşitli türde laik devlet okulları ortaya çıkmış ve faaliyet göstermeye başlamıştır. Yeni okullar Avrupa'daki çağdaşları olan eğitim kurumlarının pek çok özelliğini taşımaktaydı.

Petro'nın eğitim konusundaki girişimleri büyük ölçüde batı tarzı bir donanma, ordu ve bürokrasi oluşturma amacının yan bir ürünüdür. Onun döneminde kurulan okullar arasında Topçu Okulu, Glück Lisesi, Mühendislik Okulu, Bahriye Okulu, Madencilik Okulu bulunmaktadır. Bu okullara ek olarak onun gerçekleştirdiği eğitim reformları içerisinde açılan on iki matematik okuluyla Hollanda'ya gemicilik eğitimi almak üzere gönderilen öğrencileri de zikretmek yerinde olacaktır ${ }^{7}$. Petro açtığ 1 bu okullarda ders vermek üzere Avrupa'dan bilginler getirmiştir. 1714'te soylular için zorunlu öğretim uygulamasını başlatmıştır. Rusya' daki büyük kentlerde elli civarında ilkokul açmıştır. Devlet memurlarına matematik ve geometriyi öğrenme zorunluluğu getirmiştir. Petro'nun bu reformları 1724'te Rus Akademisi'nin açılmasına öncülük etmiştir'. Bunun yanı sıra bu yeni eğitim kurumları profesyonel bir niteliğe de sahiptir. Bu okullar içerisinde Matematik ve Denizcilik Bilimi Okulu (Школа Математических $и$ Навигацких Наук), Glück Lisesi (Гимназия Глюка), Mühendislik Meslek Yüksekokulu ve Spor Akademisi adlarından daha fazla bahsettirmiştir. Ayrıca, onun döneminde, ilk halk okullarının açılması için büyük çaba sarf edilmiştir. Bunların sonunda ise nihayet kadın eğitiminin verilebileceği eğitim yerleri için ilk projeler ortaya çıkmıştır.

\subsection{Matematik ve Denizcilik Okulu ve Rus Eğitim Tarihindeki Yeri}

Birinci Petro'nun emriyle Moskova da 14 Ocak 1701'de Matematik ve Denizcilik Bilimi Okulu kurulmuştur. Bu okul Rusya'nın ilk modern eğitim kurumlarından biri olmasının yanı sıra Rusya' da

246. [S. M. Solovyev, Antik Çağlardan Rus Tarihi: 29 Ciltlik Kitap, (Moskova: Direkt Media Yayını, 2016), 246.]

6 Марцева, “Из Истории”, 6. [Martseva, “Rus Devleti’nin”, 6.]

7 Birinci Petro, yaşamı ve reformları hakkında ayrıntılı bilgi için bk. Kezban Acar, Ortaçağ'dan Sovyet Rejimine Rusya (İstanbul: İletişim Yayınları, 2009), 141-168.

8 Mustafa Ergün, "Rus Eğitiminde Batılılaşma Çabaları ve Reformlar”, Kuramsal Eğitimbilim 2 (1) (2009): 35 .

9 И. Г. Фоккеродта, О. Плейер, Россия при Петре Великом, По Рукописному Известию (Москва: Имп. О-ва Истории И Древностей Росс. При Моск. ун-те, 1874), 101-102. [ї. G. Fokkerodta, O. Pleyer, El Yazmalarına Göre Yüce Petro'nun Egemenliğindeki Rusya (Moskova, Moskova Üniversitesi’ne Bağl1 Olan İmparatorluk Topluluğunun Tarihi ve Antik Rusya Adlı Yayını, 1874), 101-102.] 
mühendislik ve askeri eğitimin temel yapı taşı olmuştur. Okula toplumun her kademesinden öğrenci kabul edilmiştir. Buradaki eğitim süresi dört ila dokuz y1l arasında değişmekteydi. Öğrenciler 12 ila 17 yaşlarında erkek çocuklarıydı. Başlangıçta okula öğrenci bulmak oldukça zordu. Bu nedenle ilk zamanlarda 20 yaşını doldurmuş öğrenciler bile okula alınmıştır. Okul ilk başlarda 200 öğrenciyle faaliyete geçmiştir ${ }^{10}$. Ancak 1711 yılında bu sayı 500 kişiye ulaşmıştır. Öğrencilerin gördükleri dersler okur-yazarlık, coğrafya, trigonometri, denizcilik, aritmetik, jeofizik ve astronomi üzerineydi. Burada eğitim üç basamaktan oluşmaktaydı. İlk basamağa daha çok okur-yazarlığı olmayan çocuklar alınır ve çocuklar burada okuma yazmayı öğrenirdi. Okulda çoğunlukla soylu sınıfından olmayan çocuklar öğrenim görürdü. Maddi durumu elverişli olmayan birçok öğrenci bu basamakta eğitimlerini tamamlar ve eğitimleri bununla sınırlı kalırdı. Bunlar ihtiyaca göre askeriyeye veya devlet dairelerine memur olarak atanırlardı. İkinci basamakta öğrenim gören çocuklar ise aritmetik, trigonometri ve geometri eğitimi almaktaydı. Üçüncü basamakta okuyan öğrenciler soylu ve aydın kimselerin çocuklarıydı. Bu çocuklar diğer basamakların sınavlarını başarıyla tamamlamış; eğitimlerine coğrafya, denizcilik, jeofizik ve astronomi derslerini alarak devam etmişlerdir. Bu okul ilk mezunlarını 1705 senesinde vermiştir. O sene buradan mezun olan öğrenci sayısı 64 kişiydi ${ }^{11}$. 1715 yılında okulun daha üst sınıflarında öğrenim gören öğrencilerin, Moskova'dan St. Petersburg'a geçişleri yapılmıştır ve böylece St. Petersburg'da yeni bir Deniz Akademisi kurulmuştur. Deniz Akademisi'nin Matematik ve Denizcilik Bilimi Okulu'ndan bir farkı vard1. Matematik ve Denizcilik Bilimi Okulu her sınıftan öğrenci yetiştirmeye ve buradaki çocukların meslek edinebilmelerini sağlamaktaydı. Deniz Akademisi ise bu geleneği yalnız sekiz yıl sürdürmüş ve 1723 yılından itibaren akademiye sadece soylu sınıfından gelen çocukları kabul etmiştir. Yıllar sonra kurul kararı sonucunda 1752 Aralık ayında Moskova'daki okulun Denizcilik bölümü kaldırılmış ve öğrenciler St. Petersburg'a nakledilmiştir ${ }^{12}$.

\subsection{Rusya'da Bir Lise Denemesi: Glück Lisesi}

Petro döneminde Rusya'da kurulan bir diğer eğitim kurumu Glück Lisesidir. Bu okul adını, kurucusu olan Alman Papaz Ernst Glück’ten almıştır. Bu okulun ortaya çıkış hikâyesi diğer modern Rus okullarından hem biraz farklı hem de bir o kadar ilginçtir. Okulun kurucusu olan Johann Ernst Glück 1652 yılında Saksonya yakınında bulunan Wettin'de rahip bir Alman babanın çocuğu olarak dünyaya gelmiştir. Glück, İncil'i farklı dillere çevirmeyi hedefleyen bir Alman olarak bilinmektedir ${ }^{13}$. Kendisi Hristiyanlığın en eski Protestan akımlarından biri olan Lüterciliğe bağlı bir papazdır. Almanya'da aldığ 1 dini eğitimden sonra 21 yaşında Letonya'ya taşınmıştır. Glück’un yerleştiği topraklar o dönem Livonya olarak adlandırılmakta ve İsveç Kralı XI. Karl ${ }^{14}$ tarafından yönetilmekteydi. Letonya'da o dönemde insanlar genellikle eğitim almıyor, ülkede herhangi bir okul bulunmuyor ve insanlar kendi dilinde yazılmış kitaplardan yoksun bir şekilde yaşıyorlardı.

10 Г. И. Зуев, Историческая хроника Морского корпуса.1701-1925 (Москва: ЗАО Центрполиграф ООО «МиМ-Дельта», 2005), 13. [G. İ. Zuyev, 1701-1925 Ylllarında Deniz Piyadeleri Tarihi, (Moskova, Mim Delta Yayın1, 2005), 13.]

11 https://www.liveinternet.ru/users/ninapr/post428879026/, (02.04.2019/16.00).

12 https://www.liveinternet.ru/users/ninapr/post428879026/, (02.04.2019/16.00).

13 http://peshegrad.ru/articles/gimnaziya-pastora-glyuka, (15.04.2019/14:00).

14 XI. Karl 24 Kasım 1655 senesinde İsveç’te dünyaya gelmiş ve İsveç'in ilk sınır tanımayan hükümdarı olarak tarihe geçmiştir. İsveç Kralı cesaret dolu, sert, dindar ve azimli bir adamdı. Sosyal hayatın neredeyse tüm alanlarını kapsayan çeşitli reformları başlatmışıtır. XI. Karl ülkesinde mutlakıyeti güçlendirmeye çalışıp soyluların arz ve taleplerini sınırlandırmaya çalışan bir politika izlemiştir. Devletin gelişimine katkı sağlayan XI. Karl, İsveç’in en büyük krallarından biri olarak kabul edilir. İsveç Kralı 5 Nisan 1697 senesinde vefat etmiştir. A. F. Upton, Charles XI and Swedish Absolutism (New York: Cambridge University Press, 1998), 131. 
Glück, Letonya kilisesinde ana dilde İncil'in olmadığını fark ettiği an, bunun halk için büyük bir eksiklik olduğu kanısına vardı ve İncil'i Letoncaya çevirmeye karar verdi. Bunun üzerine bu dili en kısa zamanda öğrenmek ve çeviri yapabilecek bir seviyeye gelmek için olağanüstü bir çaba sarf etti ${ }^{15}$.

Glück bu isteğini ilk olarak Kral'ın Letonya'daki temsilcisi olan Johann Fisher ile paylaştı. Fisher ülkenin eğitim seviyesinin yükselmesini isteyen bir kişiydi. Glück oldukça şanslıydı çünkü Fisher'in Riga'da bir matbaası vardı. Fisher, Glück'ün Riga'ya giderek kutsal kitabı Letonca bastırabileceğini ve aynı zamanda iyi bir gelir elde edebileceğini düşünmüştü. Bunun üzerine Fisher kutsal kitabın tercümesini hayata geçirebilmek için XI. Karl'dan izin istedi. Kral Karl ise Glück'e yalnız kitap için izin vermekle kalmadı aynı zamanda kitabın tüm masraflarını üstlenmeyi teklif etti. Letonca İncil'in basılması için gerekli olan kraliyet kararnamesi 31 Ağustos 1681'de çıkarıldı ve böylece Glück'ün Letonca İncil hayalinin gerçekleşmesinin önü açıldı. Glück tercümenin daha etkili ve anlaşılır olması için kutsal kitabı orijinal dillerinden çevirmek istemiştir. Bunun için İbranice ve Yunanca öğrenmesi şarttı. Çünkü bu dillere, tercüme yapabilecek düzeyde hâkim değildi. İbranice ve Yunanca öğrenmek amaciyla Hamburg'a gitti ve burada bu dilleri öğrenmeye başladı. Burada eğitimini tamamladıktan sonra Letonya'ya döndü ve sonra kutsal kitabı tercüme edip bitirdi. Glück'ün yaptığı bu olağan üstü çalışma sayesinde artık Letonyalılar kendi dillerine çevrilmiş olan kutsal kitabı rahat bir şekilde okuyabiliyor ve anlayabiliyorlard1 ${ }^{16}$.

Glück daha sonra Kral'a kutsal kitabı Rusçaya çevirmek istediğini anlattı. Rusya'dan Letonya'ya göç etmiş olan Rusların halk arasında büyük çoğunluğu temsil ettiğini fark eden kral, Glück’ün yalnız kutsal kitabı değil aynı zamanda ders kitaplarını da Rusçaya çevirmesi gerektiğini dile getirdi. Kendisine her iki hususta da izin verdiğini belirtti. Ancak kralın 1697 yılında ölümü, halefi henüz 15 yaşındaki XII. Karl ${ }^{17}$ 'ın ise aydınlanma sorunları ile değil daha çok savaşlarla ilgilenen birisi olması Glück'ün tercümelerinin kraliyet desteğiyle gerçekleşmesine engel oldu. Glück buna aldırış etmeden tercümesine başladı ve 1699 yılında Moskova'ya bir mektup gönderdi. Mektupta ders kitaplarını ve kutsal kitabı Rusçaya çevirmekle meşgul olduğunu yazdı. Bunun üzerine Rus elçiliğinden bu tür faaliyetlerin onaylanabileceğinden bahseden bir cevap mektubu ald $1^{18}$.

Glück'ün Rus elçiliğinden olumlu cevap aldığı sıralar, 12 Şubat 1700'de, Sakson birliklerinin o tarihlerde İsveç'e ait olan Riga'yı kuşatmasıyla birlikte Büyük Kuzey Savaşı başladı. Savaşın başlıca nedenleri; Baltık Denizi'nin hangi ülkenin kontrolü altına gireceği, Rusya'nın batıda varlığını genişletme ve donanma kurma isteği ve Rus Çarı'nın Batı ülkeleriyle doğrudan ticari ilişkiler kurma arzusuydu. Savaşın başlamasıyla Glück'ün planları alt üst oldu ve ülke yöneticileri tercüme ve benzeri diğer işleri bir tarafa bırakarak savaşla ilgilenmek zorunda kaldı. Böylece Kuzey Savaşı'nın başlaması Glück'ün hayatını aniden değiştirdi. Öyle ki Rus birlikleri 1702 yılında Glück'un yaşadığı Malbork kentini ele geçirdi. Bunun üzerine Glück Ruslar tarafından esir

15 https:/travelkap.ru/statia1/gljuk/index.html, (17.04.2019/19:00).

16 https://wol.jw.org/ru/wol/d/r2/lp-u/2007444, (20.05.2019/13:00).

17 1682-1718 yılları arasında yaşayan, İsveç’in büyük hükümdarlarından birisidir. 15 yaşında ülkesinin krallı̆̆na geçen ve kendisine Osmanlılar tarafından Demirbaş Şarl lakabı da verilen XII. Karl Rusya ile çarpıştığı Büyük Kuzey Savaşları sırasında Poltova'da Büyük Petro'ya yenilince 1709-1714 yılları arasında Osmanlı Devleti'ne iltica etmiştir. Demirbaş Şarl ve Osmanlı Devleti'ndeki günlerine dair güncel bir yayın için bk. Hamza Günaydın, Burak Coşkun, “İsveç Kralı XII. Charles’ın (Demirbaş Şarl) Osmanlı Deveti'ne İlticası (1709-1714) ve İltica Süresinde Ülkesinde Ombudsman Görevlendirmesine İlişkin Bir Değerlendirme", Ombudsman Akademik 5 (9) (2018): 15-73.

18 https://wol.jw.org/ru/wol/d/r2/lp-u/2007444, (20.05.2019/16:00). 
edildi. Ruslar, Glück'ün eğitim seviyesinin yüksek olduğunu; İbranice, Yunanca, Rusça, Almanca ve Letonca bildiğini fark etti ${ }^{19}$. Birinci Petro'nun emri üzerine Glück ve o sirada Glück'ün evinde hizmetçi olarak çalışan Marta Skavronskaya adında kimsesiz bir kız çocuğu Moskova' ya gönderildi. Glück tarihi açıdan oldukça önemli bir şahsiyetti. Ancak şunu da unutmamak gerekir ki Glück ile beraber Moskova'ya gönderilen yanındaki kimsesiz küçük kız da aslında Rusya için önemli bir rol oynayacaktı. Çünkü Marta yakın bir gelecekte Birinci Petro’nun karısı ve geleceğin Çariçesi Birinci Katerina ${ }^{20}$ olacakt1 $^{21}$.

Esaretle Moskova'ya getirilen Glück Rusça bildiği için yerli halka yalnız yabancı dil değil aynı zamanda okul çağındaki çocuklara felsefe ve matematik dersleri vermeye başladı. Böylece "Glück Lisesi” 25 Şubat 1705 yılında resmi olarak faaliyete geçti. Okulun amacı çocuklara Batı Avrupa dillerini öğretmekti2 ${ }^{22}$. Bu yüzden okul Fransızca, Almanca ve Latince derslere daha fazla zaman ayırmaktaydı. Öğrenciler ana dilleri olan Rusçanın ve yabancı dillerin dışında felsefe ve coğrafyanın temelleri, doğa bilimi ve kilise dili gibi dersleri görmekteydiler. Öğrenciler burada oldukça verimli bir eğitim almaktaydılar ${ }^{23}$.

Dikkatle incelendiğinde Rusya'da Birinci Petro döneminde devlet okullarının oluşturulmasına özen gösterildiği anlaşılmaktadır. Bu yaklaşımın sonunda Rusya'da çeşitli meslek okulları ortaya çıkmıştır. Ancak Petro'nun ölümünden sonra eğitim alanındaki reformlar devam ettirilmekle beraber biraz yavaşlamıştır. Reformlardaki yavaşlama bir yana hem meslek okullarında hem de sıradan eğitim veren okullarda azalma da meydana gelmiştir ${ }^{24}$. Bununla birlikte, Büyük Petro ile Büyük Katerina arasında güçlü bir kadın çariçe olan Anna Ioannovna (1730-1740)'nın hükümdarlığ sırasında edebiyat, sanat ve müzik alanlarında ilerlemeler meydana gelmiş; bilhassa Avrupa'da iyi eğitim görmüş Almanların da yardımıyla Rusya'da kültürel anlamda bir canlılık gözlemlenmiştir. Öte yandan Rus Bilimler Akademisi de bu dönemde oldukça faal olmuştur. Büyük Petro'nun kızı Çariçe Birinci Elizabeth zamanında ise 1755'te Moskova Üniversitesi, 1757'de ise Rus Güzel Sanatlar Akademisi kurulmuştur ${ }^{25}$.

19 https://wol.jw.org/ru/wol/d/r2/lp-u/2007444, (24.05.2019/18:00).

20 Asıl adı Marta Skavronskaya olan Birinci Katerina 1684 yılında Letonya'da dünyaya gelmiştir. 1702 yılında meydana gelen Kuzey Savaşı sırasında esir düşmüş ve Birinci Petro’nun emri üzerine Moskova'ya getirilmiştir. 1712'de Birinci Petro ile evlenmiş ve böylece hayatı tamamen değişmiştir. Rusya için önemli bir şahsiyet haline gelen Birinci Katerina 1727 yılında vefat etmiştir. Марцева, "Из Истории”, 6-7. [Martseva, “Rus Devleti'nin”, 6-7.]

21 https://travelkap.ru/statial/gljuk/index.html, (17.04.2019/19:00).

22 Б. О. Васильевна, “Гимназическое Образование В России В XVIII Веке”, Молодой учёный 27(131), (2016): 646-647. [B. O. Vasilyevna, “18. Yüzyılda Rusya'da Lise Eğitimi”, Genç Bilim Adamı Dergisi 27(131), (2016): 646-647.]

23 П. П. Пекарский, Наука ИЛитература При Петре Великом Т. 1 (СПБ: Товарищества “Общественная польза”, 1862), 128. [P. P. .Pekarskiy, Yüce Petro Döneminde Bilim ve Edebiyat, 1, (St. Petersburg: Dostluk Yarı Kamu Yayını, 1862), 128.]

24 Ю. В. Стенник (Спб), “Концепция «Просвещенного Абсолютизма» В Культурной Политике Екатерины Iı”, Екатерина Великая: Эпоха Российской Истории (Санкт-Петербург: Спб Нц, 1996): 58. [YU. V. Stennik, "II. Katerina'nın Kültürel Politikasındaki "Aydınlama Mutlakiyeti” Kavramı”, Rus Tarihinde Büyük Katerina Devri Uluslararası Sempozyumu Bildirileri Kitabı içinde, (St. Petersburg: St. Petersburg Bilim Merkezi Yayını, 1996), 58.] 


\section{Katerina’nın Rus Eğitimine Katkısı ve Smolniy Enstitüsü}

Diğer ülkelerin tarihlerinde olduğu gibi Rusya'da da çarlar ve çariçeler kendi ülkelerinin tarihine farklı kimlikler ile geçmişlerdir. Örneğin, yaptıkları icraatla kimisi siyasi reformların öncüsü, kimisiyse baskıcı sistemlerin yaratıcısı olarak anılmışlardır. Bu monarkların bazıları, kendi ülkelerinin sosyal, manevi ve kültürel süreçlerini içlerinde barındıran örgütlerin organizatörü olmuş ve bu süreçte önemli roller oynamışlardır. İşte Rus tarihinde bütün bu faaliyetlere lider olmuş olan bir isim de Büyük Petro olmuştur. Büyük Petro'dan sonra bu görevi II. Katerina üstlenmiş ve "Büyük İkinci Katerina” namını almaya hak kazanmıştır. İkinci Katerina'nın Rusya'nın milli kültür tarihindeki rolü, Petro'nun ilkelerini benimsemesi ve Aydınlanma Çağı'nın ilerlediği yol boyunca Rusya'nın gelişimini yönlendirmeye devam etmiş olmasıdır. Çariçe, döneminin Rus halkı için bir lider olmak yanında ülkesinin ve halkının ihtiyacı olan kültürel bir sembol olmayı başarmıştır ${ }^{26}$. Liderlik kimliğine ek olarak bir yazar ve önemli bir düşünür de olmuştur. Kendisi Aydınlanma Çağı'nın kanun yapıcısı olarak tarihe geçmiştir. Özellikle tahta çıktığı dönemin ilk iki senesi boyunca tüm emirleri ve yasaları kendi yazmak zorunda kalmıştır ${ }^{27}$.

İkinci Katerina daha çok Batı ideolojisini ele almış ve Batı'nın önde gelen düşünürlerinin fikirlerini kullanmıştır. Bu sayede Avrupa'nın kamuoyunu kendi lehine çevirmiştir. Çariçe ülkenin iç siyasetinde halkın aydınlanması için büyük çaba harcamıştır. O, halk ile yakınlık kurabilmek adına çeşitli ülke içi seyahatler düzenlemiş; manifestolar hazırlamış ve konuşmalar yapmıştır. Örneğin, kendisi, Aydınlanma Çağı'nın Batı'daki öncülerine benzer şekilde, halkı salonlara toplar ve orada onlarla konuşmalar yapardı. Bu salonlar sadece boş vakitlerin geçirildiği, insanların birbirleriyle kaynaştı̆̆ Katerina güçlü vatansever ve aydın kişilikler yetiştirme isteğiyle 1782 yılında bir eğitim reformu gerçekleştirmiştir. Bu reformun önemi oldukça büyüktü. Çünkü ülkesi genç ve eğitimli nesillere ihtiyaç duymaktaydi ${ }^{29}$.

\subsection{Smolniy Enstitüsü’nün Kuruluşunu Etkileyen Dış-Ị̇c Faktörler ve Kuruluşu}

Aydınlanma düşüncesi Montesquie'den Voltaire, Diderot, Hume ve Rousseau'ya kadar oldukça geniş bir alana yayılmaktaydı. Katerina bu düşünürlerin görüşlerinden hareketle kendi sentezini oluşturmuştu. Bazı filozoflarla uzun yazışmalar yapmıştı. Rusya'ya ilgi duyan Voltaire ve Diderot bu düşünürlerden belki de onu en çok etkileyenleriydi. Öyle ki Diderot, Katerina'dan aldığı destekle kütüphanesini kurtarabilmiş; belki de borçluluk duygusunun bir sonucu olarak 17731774'te Rusya'ya gitmiş; Çariçe Katerina'nın karşılıklı konuşma fırsatı bulduğu ilk fillozoflardan birisi olmuştur. Aydınlanma, Rusya'da eğitim faaliyetlerini de kapsayan bir görüntü içermekteydi.

26 М. С. Каган, “О Роли Екатерины Великой В Истории России”, Екатерина Великая: Эпоха Российской Истории (Санкт-Петербург: Спб Нц, 1996), 72. [M. S. Kagan, "Yüce Katerina’nın Rus Tarihindeki Rolü”, Rus Tarihinde Büyük Katerina Devri Uluslararası Sempozyumu Bildirileri Kitabı içinde, (St. Petersburg: St. Petersburg Bilim Merkezi Yayını, 1996), 72.]

27 Каган, “О Роли Екатерины”, 73. [Kagan, “Yüce Katreina’nın”, 73.]

28 М. И. Микешин, “Просвещенная Монархия Как Идеология” Екатерина Великая: Эпоха Российской Истории (Санкт-Петербург: Спб Нц, 1996),: 79. [M. İ. Mikeşin, “İdeoloji Olarak Aydınlanmış Monarşi”, Rus Tarihinde Büyük Katerina Devri Uluslararası Sempozyumu Bildiriler Kitabı içinde, (St. Petersburg: St. Petersburg Bilim Merkezi Yayını, 1996), 79.

29 В. И. Моряков, “Екатерина II И Русские Просветители О Воспитании «Истинного Сына Отечества»”, Екатерина Великая: Эпоха Российской Истории (Санкт-Петербург: Спб Нц, 1996), 81. [V. İ. Moryakov, "II. Katerina ve Rus Eğitim Aydınları “ Gerçek Anavatan Evladı", Rus Tarihinde Büyük Katerina Devri Uluslararası Sempozyumu Bildiriler Kitabı içinde, (St. Petersburg: St. Petersburg Bilim Merkezi Yayını, 1996), 81. 
Petro'nun Bilimler Akademisi, Elizabeth'in Sanatlar Akademisi, Moskova Üniversitesi halihazırda mevcut önde gelen yüksek öğretim kurumlarıydı. Katerina döneminde eğitime ilişkin çağdaş bir anlayış kadınların da eğitimini içerecek şekilde ileriye dönük bazı deneyimler ve fikirler getirdi ${ }^{30}$.

Gerek İkinci Katerina gerekse onun öncülerinin dönemleri incelendiğinde Rus eğitim sistemini etkileyen birçok Batı Avrupa ülkesine rastlamak mümkündür. $O$ dönemin Rusyası hakkında günümüzde hala tartışma konusu olan ve sıkça sorulan bir takım sorular vardır. Bunlardan birisi İkinci Katerina'nın hâkimiyeti sırasında daha çok hangi Avrupa ülkesinin Rus kültürünü etkilemiş olduğu sorusudur. Soruyu soran birçok bilim insanı bu etkinin daha çok Fransa ya da Birleşik Krallık ${ }^{31}$ merkezli mi olduğuna kafa yormuşlar ve sorunun cevabını farklı açılardan vermeye çalışmışladır. Bununla birlikte, İkinci Katerina fikren İngiliz ve pratikte Avusturyalılar ve Fransızlardan yararlanmıştır. Örneğin kendisi daha çok İngiliz bilim adamları, felsefecileri ve ekonomistleri tarafından yazılan; Alman ve Fransız diline tercüme edilmiş olan eserleri okumaktan keyif alıyordu. Aynı zamanda II.Katerina, David Hume ${ }^{32}$ ve William Robertson ${ }^{33}$ 'un tarih eserlerine büyük bir hayranlık beslemekteydi ${ }^{34}$.

Rusya'nın başına geçtikten sonra İkinci Katerina'nın edebiyata olan merakı daha da artmış ve daha çok Fransız dilinde yazılar yazmaya başlamıştır. Dahası çariçe, Fransız yazarların stil ve tarzlarını mükemmel bir şekilde benimsemiştir. Elimizdeki bilgilerden yola çıkacak olursak II. Katerina Rusya'sında, Fransız dili ve kültürü aydın Ruslar arasında oldukça egemen bir hal

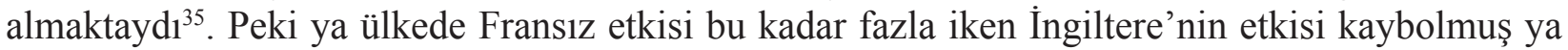
da bastırılmış olabilir miydi? Tabi ki hayır. İngiltere'nin sarayda ve aydın Rus tabakası üzerindeki egemenliği devam etmekte ve eski yerini korumaktaydı. Sadece dil ve kültür bakımından değil eğitim sistemindeki yeri hala aynıydı. Esasında, İkinci Katerina Fransız dilini beğenmesine rağmen Fransız eğitim sistemine eleştirel bir şekilde yaklaşmaktaydı. Aynı zamanda 18. yüzyılda Rus halkının eğitim sistemini etkileyen ve bu sistemde egemen olan Fransız eğitim sistemine de dikkatle ve kontrollü bir biçimde yanaşmaktayd $1^{36}$.

İkinci Katerina’nın kız çocuklarına yönelik yapılan eğitim projelerinde İngiliz etkisi daha çok fikri manada kendisini göstermiştir. Bu projelerde, İngiliz etkisinin izlenilme sebebi İngiltere'de

30 Nesrin Sarıahmetoğlu, "Rusya İmparatorluğu", Rusya Tarihi içinde, ed. Nadir Devlet ve Nesrin Sarıhmetoğlu, (Ankara: Anadolu Üniversitesi Yayını, 2013), 114.

31 David Bayne Horn, Great Britain and Europe in the Eighteenth Century (California: Clarendon Press, 1967), 213.

32 David Hume (1711-1776) İskoç Aydınlanmasının önemli filozoflarından birisidir. Felsefe konularını ele aldığı "A Treatise of Human Nature (İnsan Doğası Üstüne Bir İnceleme 1739-1740) "adlı çalışması alanında bir başyapıttır. Bk. Mustafa Çevik, "David Hume'da Din ve Tanrı Anlayıı̧ı”" (Doktora Tezi, Ankara Üniversitesi Sosyal Bilimler Enstitüsü, 2003), 7.

33 William Robertson 19 Eylül 1721 yılında Midlothian'da dünyaya gelmiştir. Robertson, 18.yüzyılın en önemli İngiliz tarihçilerinden biri olarak kabul edilmektedir. Uzun yıllar İskoç Kilisesi’nin yöneticiliğini ve Edinburgh Üniversitesi’nin idaresini üstlenmiştir. Çalışmalarında eğitim paradigmalarını kullanmış ve geliştirmiştir. Eserlerinde insanlık tarihinin sosyal-psikolojik yönünü işlemiştir. Robertson 11 Haziran 1793 yılında hayatını kaybetmiş̧ir. Bk. E. Adamson Hoebel, "William Robertson: An 18 Century Anthropologist-Hisatorian”, American Anhropologist 62 (4) (1960): 648-655.

34 Horn, Great Britain, 213.

35 В. О. Ключевский, Сочинения $B 9$ Томах-Том 5, (Москва: Мысль, 1989), 29. [V. O. Klyuçevskiy, 9 Ciltte Eserler Kitabı-5.Cilt, (Moskova: Düşünce Yayın1,1989), 29.]

36 Ю. А. Лимонова, Россия XV-XVII вв. Глазами Иностранцев, (Ленинград: Лениздат, 1986), 342. [Yu. A. Limonova, Yabancıların Gözünden 15.-17. Yüzyllda Rusya Kitabl, (St.Petersburg: Lenizdat Yayın1, 1986), 342.] 
daha önce böyle bir kurumun faaliyet göstermiş olmasıdır. Örneğin, İngiliz yazar ve aynı zamanda gazeteci olan Daniel Defoe ${ }^{37}$ "Projeler Hakkında Deneme" adlı bir eser ortaya koymuştur. Defoe kız çocuklarının aydınlanmanın faydalarından mahrum bırakılması fikrine daima karşı çıkmıştır. Defoe kız çocuklarının doğuştan itibaren becerikli ve öğrenmeye yatkın olduklarını savunmuştur. Eğitim alanında profesyonel olmamasına rağmen erkekler için askeri akademiler ve kızlar için eğitim akademileri oluşturma konusundaki özgün projelerini sunmayı başarmıştır. Defoe "Projeler Hakkında Deneme" eserinde eğitim kurumlarının kurulmasını ve burada aristokrat kız çocuklarının yetiştirilmesini teklif etmiştir. Bu kurumların kapalı tip pansiyonlar olması, kız çocuklarının laik bir eğitim almaları, okuryazarlığı bilmeleri ve bunların yanında yabancı dil, müzik ve dans1 öğrenmeleri konularında tavsiyelerde bulunmuştur. Zamanla bu projeler hayata geçirilmiş ve 17. ve 18.yüzyılda bu gibi pansiyonlar oldukça popüler hale gelmiştir. Hatta hem yüksek hem de orta sınıf tabakaya hitap eden bu özel pansiyonlar İngiltere'de sıradanlaşmaya başlamıştır ${ }^{38}$.

İkinci Katerina Birinci Petro'nun açtığı mesleki okulların şekli ve sayısından ziyade bu eğitimin temeliyle ve kapsayıcı olmasıyla yakından ilgilenmiştir. Eğitim alanında Çariçe'nin en büyük yardımcısı İvan Betskoy olmuştur. Betskoy, 1764 yılında Katerina'nın önerdiği ve genel eğitim ilkelerini sıraladığı "Her İki Cinsten Gençlerin Eğitimi İçin Genel Plan" adı altında bir çalışma hazırlamıştır. Bu ilkelerin ilk somut uygulaması 1764'te Moskova'da ve 1770'te StPeterburg'da, Katerina ve Betskoy'un kurdukları kimsesiz çocuklar yurtlarında yapıldı. Burada eğitim alanlar, çeşitli zanaatlarda usta olacaklar, toplum içinde Tanrı'nın kendilerine verdiği görevleri yerine getireceklerdi. Bunun yanı sıra temel eğitimi yaymak için 1767 yılında az gelirli soylular için taşra okullarının açılması emri verilmiştir ${ }^{39}$.

Katerina’yı eğitim sorununu ulusal çapta ele almaya yönelten etkenin Rusya' da bir milli okul sisteminin ancak devlet eliyle kurulabileceğini anlaması gösterilebilir. Nedeni ne olursa olsun, 1782 yılında İkinci Katerina'nın isteği üzerine Avusturya İmparatoru İkinci Joseph, Rusya’ya eğitim alanında çok deneyimli bir pedagog olan Sırp asıllı Jankovič Mirijevski'yi görevlendirmiştir. Jankovič Mirijevski'nin görevi, Rusya'da ilkokul sistemini ve müfredatını oluşturmaktı. Mirijevski'nin halk okullarına yönelik reformu okulları üç gruba ayırmaktaydı: iki sınıftan oluşan "Küçük Okullar", üç sınıftan oluşan “Ortaokullar” ve dört sınıftan oluşan “Anaokulları”. Tüm bu okulların birinci sınıfında "Okuma, Yazma, Rakamlar", ikinci sınıfta "Aritmetik, Güzel Yazı, Çizim, Din Bilgisi, Vatandaşın Görevleri”, üçüncü sınıfta "İncil Okuma, Rusça Dilbilgisi, Genel Tarih, Coğrafya”, dördüncü sınıfta ise "Rusça Dilbilgisi, Geometri, Genel Tarih, Genel Coğrafya, Mekanik, Fizik, Mimarlık” dersleri okutulurdu. Ayrıca Çariçe 1785 yılında, Mirijevski'den özel okullar ve pansiyonlar için de bir müfredat oluşturmasını istemiştir. İkinci Katerina, bir yıl sonra 5 Ağustos 1786 tarihinde tüm halk okulları ve özel okulların Genel Denetim Komisyonu'nun kararlarına tabi tutulması emrini vermiştir. Böylece bu kararlarla tüm okullar Genel Denetim Komisyonu'nun çatısı altında toplanmış ve bir anlamda Rusya'nın Milli Eğitim Enstitüsü oluşturulmuştur ${ }^{40}$.

İkinci Katerina kız çocuklarının eğitimini oldukça önemsemiş ve bunun için büyük çabalar

37 Daniel Defoe 13 Eylül 1660'ta Londra'da dünyaya gelmiştir. İngiliz romanında ve çağdaş gazetecilik alanında oldukça kapsamlı yapıtlar ortaya çıkarmıştır. Robinson Crusoe adlı roman yazarın, en ünlü eseridir. Daniel Defoe 23 Nisan 1731 yılında vefat etmiştir. Daniel Defoe, Robinson Crusoe, çev. Akşit Göktürk (İstanbul: Yapı Kredi Yayınları, 2016), İç kapak.

38 Е. Ф. Петинова, Во дни Екатерины, (СПБ: Книжный Мир, 2002), 48. [YЕ. F. Petinova, Katerina Günlerinde, (St. Petersburg: Kitap Dünyası Yayını, 2002, 48.]

39 Zulfiya Şahin, “XVIII. Yüzyılın İlk Yarısında Rusya’nın Kültürel Gelişimi ve Batıya Uyum Çabaları”, Ankara Üniversitesi Sosyal Bilimler Dergisi 5 (2) (2014): 176-177.

40 Şahin, "XVIII. Yüzyılın”, 177. 
sarf etmiştir ${ }^{41}$. Bu yüzden 5 Mayıs 1764 yılında İvan Betskoy ${ }^{42}$ 'un projesi olarak İkinci Katerina'nın kararı ile asıl adı "İmparatorluğun Soylu Genç Kızlarının Talim ve Terbiye Topluluğu” veya "Soylu Genç Kızlar Enstitüsü”, diğer bir adı "Smolny Enstitüsü” olan kadın eğitim kurumu ortaya çıkmıştır ${ }^{43}$. Bu okulda kızlar aile yaşamının cehalet ve zalimliğinden korunurlardı. Doğrudan doğruya Betskoy'un denetimde olan kimsesizler yurtlarında ve Smolniy Enstitüsü'nde bedensel ceza kesinlikle yasaktı ve çocukların başka insanlara 1stırap verildiğini görmemeleri için hizmetkârlar bile dayakla cezalandırılmazdi ${ }^{44}$.

İşte İkinci Katerina 17. ve 18. yüzyıl İngiltere'sinde ortaya çıkan fikirlerden ve Fransa'dan esinlenerek Rusya'da daha önce benzeri görülmeyen bir enstitü kurmuştur. İkinci Katerina enstitüye kurmadan bir yıl önce Hollanda'nın şehri Lahey'de, Almanya'nın başkenti Berlin ve bir diğer şehri olan Hamburg'da, İsveç'in Stockholm şehrinde, Avusturya'nın başkenti Viyana'da ve son olarak da Danimarka'nın Kopenhag şehrinde bulunan Rus elçiliklerinde görev yapmakta olan diplomatlarından bir istekte bulunmuştur. Diplomatların temsilcisi oldukları şehirde bu gibi kurumların hepsi veya en iyileri hakkında kendisine en kısa zamanda ayrıntılı bir açıklama yapmalarını talep etmiştir. Ancak yazışmalar sonucunda ilgisini çekebilecek bir bilgi elde edememiştir ${ }^{45}$. Her ne kadar İkinci Katerina fikren İngiliz etkisinde kalsa da Fransa' da Madame de Maintenon tarafından kurulan St. Cyr Okulu'nu örnek alarak Smolniy Enstitüsü’nü kurmuştur ${ }^{46}$.

\subsection{Smolniy Enstüsü’nün İşleyişi}

Smolniy Enstitüsü Rusya'da kadın eğitimine uzunca bir süre örnek olmuştur. İkinci Katerina'dan itibaren Rusya' da açılan kadın eğitimi kurumlarının asıl amacı genç kızlara talim ve terbiye vermekti. Daha sonraki aşamada bu genç kılara yabancı dilleri öğretmek ve el sanatları becerilerini geliştirmekti. Bunların yanı sıra enstitüde her biri temizlik, yemek yapma gibi ev işleri becerilerini geliştiren dersler yer alıyordu. Bu eğitim kurumunda eğitim alan genç kızlar enstitüye beş altı yaşında kabul ediliyor ve burada 12 sene aralıksız bir şekilde eğitim alıyordu. Genç kızların talim ve terbiyesi ile kadın öğretmenler ilgileniyor ve aynı zamanda genç kızları yine onlar denetliyordu ${ }^{47}$.

41 Э. П. Юровская, “Утопические Черты Организации Императорского Воспитательного Общества Благородных Девиц”, Екатерина Великая: Эпоха Российской Истории (Санкт-Петербург: Спб Нц, 1996): 107-108. [E. P. Yurovskaya, "İmparatorluğun Soylu Genç Kızlarının Talim ve Terbiye Topluluğu” veya “Soylu Genç Kizlar Enstitüsü’nün Ütopik Özellikleri”, Rus Tarihinde Büyük Katerina Devri Uluslararası Sempozyumu Bildiriler Kitabı içinde, (St. Petersburg: St. Petersburg Bilim Merkezi Yayın1, 1996), 107-108.]

42 İvan Betskoy 14 Şubat 1704'te Stockholm'da dünyaya gelmiştir. Uzun yıllar yurt dışında yaşamış ve tahsilini orada tamamlamıştır. 1721 senesinde Rusya'ya gelen Betskoy bildiği yabancı diller sayesinde Birinci Petro'nun dikkatini çekmiş ve dönemin dış işleri komitesine katılmıştır. Daha sonra buradan ayrılmış ve hayatını eğitime adamıştır. İvan Betskoy Rus eğitim hayatına büyük katkılar sağlamış ve genç neslin eğitimi ile yakından ilgilenmiştir. Betskoy 10 Eylül 1795 senesinde vefat etmiştir. Е. М. Колосова, “Он Жил Для Всех. К 305-Летию Со Дня Рождения И.И.Бецкого”, Вестник Герценовского университета 1(63) (2009): 72-74. [Ye. M. Kolosova, "O Herkes İçin Yaşadı. İvan Betskoy’un 305. Yaş Gününe İthafen”, Rusya Herzen Üniversitesi Haberleri Dergisi, 1 (63) (2009): $72-$ 74.

43 В. Б. Помелов, “Смольный Институт Блогадарных Девиц”, Начальная Школа, 2 (2015): 84. [V. В. Pomelov, “Soylu Genç Kızlar Smolniy Enstitüsü”, İlkokul Dergisi, 2 (2015), 84.]

44 Şahin, "XVIII. Yüzyılın”, 177.

45 Петинова, Во дни Екатерины, 48. [Petinova, Katerina Günlerinde, 48.]

46 Şahin, "XVIII. Yüzyılın”, 177.

47 3. Е. Мордвинова, “Смольный институт в эпоху императрицы Екатерины II (1764-1796)”, Вопр. 
Smolniy Enstitüsü kadın eğitimine yönelik açılmış Rusya'da ilk enstitü olup İkinci Katerina'nın bu okulu açmasının bir amacı da devletin eğitimli kadınlar yetiştirmesi, genç kızların ileride iyi birer anne olmasının sağlanması ve topluma yararlı birer birey kazandırılmasıydı ${ }^{48}$. Smolniy Enstitüsü soylu genç kızlar için kapalı bir eğitim kurumu haline gelmiştir. Kurumun kendine has kapalı bir ortam olması İvan Betskoy'un fikri ve şartıydı. İvan Betskoy’un fikrince kurum oldukça ideal bir ortama sahipti. Genç kızlar toplumdan, ailelerinden ve çevreden tamamen arınmıştı. Aldıkları 12 sene eğitim süresince genç kızlar ahlaksızlıklardan uzak birer yetişkin kadın haline geliyordu. Her biri anne olduklarında aldıkları eğitim sayesinde topluma yararlı bir birey haline gelecek çocuklar yetiştirebileceklerdi. Enstitü oldukça disiplinli ve sert kuralları olan bir eğitim kurumuydu. Bu yüzden genç kızlar kurumun kuralları çerçevesinde yaşıyor; aileleri ile yalnızca hafta sonları veya bayramlarda, başlarında bir müdür olması şartıyla, görüşebiliyordu. Bu genç kızlar oldukça şanslıydı ancak aileleri uzak bir memlekette olan genç kızlar bu konuda büyük zorluklar çekmiştir ${ }^{49}$. Çünkü aileleri ile aylarca görüşemiyor ve ailelerine yazdıkları karşılıklı mektuplar sınıf rehberleri tarafından okunuyor ve kontrol ediliyordu. 18 yaşını doldurmadan genç kızlar ne kendileri ne de ailelerinin isteği ile bu eğitim kurumunu terk edemiyordu. Bu kızlar eğitim kurumuna alınmadan önce ailelerinden kızlarının 12 sene süren eğitim hayatını tamamlamadan onları hiçbir şekilde geri alamayacaklarına dair bir dilekçe isteniyordu. II. Katerina genç kızları bulundukları eğitimsiz ortamlardan uzun bir süre uzaklaştırmayı ve bu süre zarfında aldıkları eğitim sayesinde geldikleri yerlere çok daha eğitimli ve ahlaklı bir şekilde dönmelerini umut

Образования 3 (2007): 256. [Z. YE. Mordinova, "İmparatoriçe II. Katerina Döneminde Smolniy Enstitüsü (1764-1769)", Ĕgitim Sorunları Dergisi 3 (2007): 256.]

II. Katerina ve onun açtığı Smolniy Enstitüsü hakkında Türkiye'de başlı başına bir monografik esere rastlamak oldukça zordur. Bununla birlikte, Fransız tarihçi ve çevirmen Castera tarafından Fransızca olarak kaleme alınan, Yakovaki Efendi tarafından Osmanlı yazısıyla kaleme alınmış bir tercüme eser vardır. Çeşitli yazmaları olan bu tercüme farklı nüshalar karşılaştırılarak Mehmet Mercan tarafından transkribe edilerek günümüz Türk alfabesine kazandırılmıştır. Bu eserde bir bölüm Katerina’nın yaptığı eğitim reformlarına ayrılmıştır. Bu kitapta Katerina’nın açtığı ifade edilen altı okul türünden beşincisi olarak Smolniy Enstitüsü’ne değinilmiştir. Bu okul için eserde şu ifadeler dikkati çekmektedir. "Tâ'ife-i nisvânın ta'lîm ve terbiyesine mahsûs olan ta'lîm-hânedir. Derûnunda mîrî masrafiyla ta'ayyüş iden dört yüz seksen şâkird vardır. Nısf-1 mikdârı ashâb-1 asâletin ve nısf-ı âheri sâ'irlerin kızlarından 'ibâretdir. Bu ta'lîm-hânenin muhâfaza-i nizâmında bir nâzıra ve yine tâ’ife-i nisâdan sekiz nefer yamaklar ve kırk nefer mu'allimeler vardır. Marü'z-zikr kız şâkirdlere milel-i sâ’ire-i Efrenciye lisânları ve bâ-husûs Fransız lisânı ve usûl-1 âyîniye ve fenn-i târih ve coğrafya ve rakam ve musiki ve raks derslerinden mâ'ada 'ilm-i tedbir-i menzil dahî ta'lîm olunur. Mersûmelerin sinni altı seneden ziyâde olur ise derûn-1 ta'lîm-hânede kabul olunmamak ve on iki sene müddet ta'lîmlerinden sonra on sekiz seneye vardıkda her biri akrabasına teslîm olunmak ve tekmîl-i ders eyledikden sonra ashâb-1 asâlet kızlarından ise her birine cânib-i mirîden cihâz olarak iki bin ruble ve âhâd-ı nâsdan ise yüz ruble ihsân olunmak muktezâ-yı nizâm-1 ta 'lîm-hânedendir. İrâd-1 senevîsi yüz seksen bin rubledir.” Bu ifadelerde aktarıldığına göre söz konusu okulda dört yüz seksen kızın eğitim aldığı; okulun öğrencilerinin yarısının asillerin, yarısının halkın aşağı kesimlerinin kızlarından oluştuğu; okulda bir nazır, sekiz yamak ve kırk öğretmen bulunduğu; okulun dersleri içerisinde bilhassa Fransızca olmak üzere yabancı dil, tarih, coğrafya, müzik ve dans derslerinin yer aldığ rine teslim edildiği ve kendilerine belirli miktarda çeyiz parası verildiği anlaşılmaktadır. Bk. Mehmet Mercan, Katerina Tarihi (Ankara: Karaman Bilim ve Araştırma Merkezi Yayını, 2010), 222.

48 А. Н. Поздняков, “Институты благородных девиц в системе образования России второй половины XVIII-начала XIX века”, Изв. Сарат. ун-та. Нов. сер. Сер. Философия. Психология. Педагогика 2 (4) (2014): 104. [A. N. Pozdnyakov, “18. Yüzyılın İkinci Yarısı-19.Yüzyılın Başlarında Rusya’nın Eğitim Sisteminde Soylu Genç Kılar Enstitüsü”, Saratov Üniversitesi Haberler Dergisi,2 (4) (2014): 104.]

49 Поздняков, “Институты благородных”, 105. [Pozdnyakov, “18. Yüzyılın”, 105.] 
ediyordu. Senatoya her şehre ve her vilayete soyluların eğer isterlerse kızlarını enstitüye emanet edebileceklerine dair bir yazı göndermeleri için izin verilmiştir ${ }^{50}$.

1764 yılında beş ve altı yaşlarında 60 kız çocuğu okula kabul edilmiştir. Enstitünün verdiği eğitim ve terbiye çocukların yaşlarına göre sınıflara ayrılmıştı. Yani 12 sene eğitim ve terbiye veren bu kurumda ilk önce dört ana yaş grubu vardı. Daha sonra bu dokuz seneye düşünce bu sefer kurum üç ana yaş grubu ile devam etmiştir. Enstitünün kendine özgü bir giyim kuralı vardı. Örneğin, her yaş grubuna ait bir elbise ve her elbisenin yine yaş gruplarına göre değişen bir rengi vard1. Bu elbiseler kısa kollu ve yırtmaçlıydı. En küçük yaş grubu olan yani 7 yaşındaki çocuklar kahverengi, 8 veya 10 yaşındakiler mavi veya lacivert, 11 veya 13 yaşındakiler gri ve son olarak yaşları biraz daha büyük olanlar beyaz elbiseler giyerdi. Kahverengi toprağın bir sembolüydü yani yeryüzünü simgelerdi. Özellikle küçük çocuklar için daha elverişli bir renkti. Daha açı renkler ise eğitimin, ilerleyişinin ve düzenliliğin sembolüydü. Enstitü yapısındaki hayat sadeliği ile diğer kurumlardan her zaman ayırt edilirdi ve enstitüde temizliğe oldukça önem verilirdi ${ }^{51}$.

Genç ve küçük kızların günlük programları oldukça katıydı. Öğrenciler her sabah saat altıda kalkıyor, derslere giriyor ve daha sonra başlarında nöbetçi bir kadın öğretmen olması şartıyla hava alabiliyorlardı. Alt yaş grubuna ait kızlara din, Rus dili ve diğer yabancı diller, matematik, resim, müzik, dans ve el becerileri dersleri veriliyordu. Bir üst grubun öğrencileri yukarıda bahsettiğimiz derslere ilave olarak tarih ve coğrafya derslerini alıyordu. Son ve en üst yaş grubuna ait genç kızlara ise sosyal bilimler, heykel, mimarlık, fizik, arma bilimi ve tornacilık dersleri verilirdi. Son gruptaki öğrenciler alt gruptaki kız öğrencilerin derslerine katılır ve böylece bir nevi staj yapard $1^{52}$.

50 Ю. М. Лотман, Беседы о русской культуре.Быт $и$ традиции русского дворянства (XVIII-начало XIX века) (Санкт-Петербург: Искусство-СПБ, 1994), 100. Yu., M. Lotman, Rus Kültürü Hakkında Sohbetler ve Rus Soyluların Gelenekleri (18.Yüzyılın Başları-19.Yüzyıl), (St. Petersburg: Sanat-St. Petersburg Yayın1, 1994), 100.]

51 Лотман, Беседы $о$ русской, 100 vd. [Lotman, Rus Kültürü, 100 vd.]

52 И. И. Бецкой, Устав Воспитания Двухсот Благородных Девиц, Учрежденного Императрицей Екатериной II. (СПБ: 1764), 4- 6 [İ. İ. Betskoy, İmparatoriçe II. Katerina’nın Kurduğu 200 Soylu Genç Kızlar Talim ve Terbiye Okulunun Tüzüğ̈̈, (St. Petersburg 1764), 4-6. Soylu Genç Kızlar Enstiitüsü’nün Tüzüğü başlığıyla kaleme alınan Smolniy Enstitüsü tüzüğü 1764 senesinde St. Petersburg'da Rusça “Устав Воспитаия Двухсот Благородный Девиц Учрежденного Ее Величеством Государению Императрицаю Екатериною Второю Сомодержицею Всеросийскою Матерью Отечества И Протчая И Протчая И Протчая"; Türkçe “Tüm Rusya’nın, anavatan ve diğerlerinin annesi olan Çariçe II. Katerina majesteleri tarafından kurulan iki yüz asil genç kızın eğitim tüzüğü...” başlığı altında enstitünün var olmasını sağlayan II. Katerina’nın fermanı sonucunda ortaya çıkmıştır. Başlığıın hemen altında II. Katerina'ya ithafen yazılmış bir teşekkür mektubu bulunmaktadır. Вk. Бецкой, Устав Воспитания., 1.[Betskoy, İmparatoriçe II. Katerina’nın, 1.] Tüzük iki kısımdan ve altı bölümden oluşmaktadır. İlk kısımda altı ara bölüm olup her biri farklı başlıklar altında toplanmaktadır. Birinci bölümde mütevelli heyetinin görevleri ve soylu genç kızların pansiyonlara hangi şartlar altında alındıklarını anlatan on madde bulunmaktadır. Bk. Бецкой, Устав Воспитания., 3-4. [Betskoy, İmparatoriçe II. Katerina'nın, 3-4.] Tüzüğün birinci kısmının ikinci bölümü dört farklı ana başlığa ayrılmakta olup genç kızların öğretmenleri ve aldıkları dersler hakkında bilgiler verilmektedir. Birinci grup 6 ila 9 yaş arası kız çocuklarına ayrılmaktadır. Burada kadrolu olarak bayan denetleyici, bayan öğretmen ve hizmetli görev yapmaktadır. Öğrencilerin gördükleri dersler, anayasa ve dini kanunlar, her yaş grubu için terbiye ve erdem, Rusça ve yabancı diller, aritmetik, resim, dans, vokal, enstrümantal müzik, dikiş ve örgüdür. İkinci yaş grubu 9 ila 12 yaş arasındaki kız öğrencilerdir. Bir önceki yaş grubundaki elemanlar ikinci yaş grubunda çalışmaya devam etmekteydi. Ancak buradaki tek fark kız çocukları artık birer genç kız olmaya başladıkları için yataklarını kendileri toplar, saçlarını kendileri yapar ve temizlik işlerini kendileri yerine getirmeye başlardı. Birinci grubun derslerine sadık kalınarak coğrafya, tarih, ekonomiye giriş ve çizim gibi birkaç ders daha eklenirdi. Üçüncü yaş grubunda 12 ila 15 yaşındaki genç 
Smolniy Enstitüsü'nün tek amacı eğitim vermek değildi. Çünkü İkinci Katerina enstitüyü kurmaya karar verdiğinde buradaki genç neslin eğitimli birer genç kız olmalarının yanı sıra bu genç kızların ilerideki hayatlarında insanlarla nasıl konuşulması gerektiğini ve görgü kurallarını kurumda kaldıkları süre zarfında öğrenmeleri için büyük çaba harcamış ve bu konu ile bizzat kendi ilgilenmiştir. Kurumda gerçekleşen bir suçtan dolayı fiziksel cezalar vermek tamamen yasaktı. Cezalar daha çok öğrencileri sınıfın içinde sözlü olarak uyarmak ve diğerlerinin bundan örnek almasını sağlamaktan yanaydı. Enstitünün kuralları oldukça katı olduğundan suçlar hafif dahi olsa disiplin cezası verilebilirdi. Örneğin, ders aralarında koridorlarda yüksek sesle konuşmak, yatakların çarşaflarını kırışık şekilde bırakmak, giydikleri elbiselerin herhangi bir eksiği olması veya tokaların arasından çıkmış bir saç dahi suç sayılır ve bundan dolayı disiplin cezası alınabilirdi ${ }^{53}$.

Smolniy Enstitüsü'nde öğretmenler, hizmetliler ve senato üyeleri olarak toplam 178 kişi $^{54}$ çalışmaktaydı. Çalışanlar enstitüde ikamet edenler, ikamet etmeyenler ve saat hesabı olarak çalışanlar olmak üzere üç gruba ayrılmaktaydı (Krş. Tablo 1, 2 ve 3.). Ancak enstitüye öğretmen alımlarında dikkat edilen önemli bir nokta vardı. Alınan öğretmenlerin genelde bekâr olmasına dikkat edilirdi. Dönemi gereği evlilik bir genç kız için oldukça önemliydi. Ancak evliliklerinde sorunlar yaşayan kadınların bu sorunları dışarıdaki hayatlarına yansıtmaları olumsuz bir davranış göstergesiydi. Bu tür sorunları olan öğretmenler bunu öğrencilerine yansıtır ve onların en ufak hatalarında dahi olmadık tepkiler gösterebilirdi. Bu yüzden bekâr olan kadın öğretmenler daha çok tercih edilirdi. İlginçtir ki erkek öğretmenler ise işe alınırken daha çok evli ve eğer evli değilse de yaşlı veya yakışıklı olmayan alımsız olanlar tercih edilirdi. Bunun sebebi ise genç kızlarla aralarında olabilecek herhangi bir aşk veya izdivacı engellemekti ${ }^{55}$.

Sınıf öğretmenleri hariç diğer tüm öğretmenler saat başına ücret alarak çalışırdı. Enstitüde hem çalışıp hem ikamet edenler arasında enstitünün müdiresi, genç kızları denetlemekten sorumlu denetleyici, yine genç kızların mürebbiyesi, her gruba ait olan sınıf öğretmenleri, genç kızların ilk okuma ve yazma gibi eğitimlerini üstlenen rahibeler, başhemşire ve yardımcısı, hasta bakıcılar, ilk iki yaş grubunun yemeklerinden sorumlu aşçı ve yardımcıları, bulaşıkçılar, küçük kızların banyo ve temizliklerinden sorumlu hamamcılar ve kapıcılar yer almaktadır. Enstitü dışında ikamet

kızlar öğrenim görmektedir. Burada çalışan kadrolu çalışanlar bayan denetleyici, bayan öğretmen ve hizmetlilerden oluşmaktadır. Ancak burada genç kızlar neredeyse tüm işleri kendileri görürdü. Burada bir önceki yaş grubunda görülen derslere ilave olarak genç kızlar tarihi ve dini kitapların okunması, mimarlık, hanedan armalarının tarihçeleri ve ekonomi derslerini görmektedir. Dördüncü ve son grupta öğrenim gören genç kızlar 15 ila 18 yaş arasındadır. Burada öğrenim gören genç kızların öğretmenleri ve diğer çalışanlar hakkında bir bilgi verilmemektedir. Gördükleri dersler üçüncü yaş grubundakilerle aynı olup onlara ek olarak kendilerine hukuk bilgisi, genel terbiye kuralları, erdem, sosyal yaşam ve nezaket kuralları dersleri verilmektedir. Tüzüğün İkinci bölümü “Ancak aldıkları bütün yaş gruplarındaki derslere bakmayarak genç kızlar tam anlamıyla eğitimli sayılmaktadır." gibi ilginç bir cümle ile sona ermektedir. Bk. Бецкой, Устав Воспитания., 4-6. [Betskoy, İmparatoriçe II. Katerina’nın, 4-6.]Tüzüğün üçüncü bölümünde müdirenin görevleri on iki; dördüncü bölümde enstitünün yöneticisinin görevleri dokuz; beşinci bölümde denetleyici, gözcü ve nezaret eden hanımların yapacakları işler on bir; altıncı bölümde usta öğreticiler ve öğretmenlerin görevleri on dokuz maddeyle sıralanmıştır. Böylece tüzüğün ilk kısmı sona ermektedir. İkinci kısımda enstitünün elemanlarından kırk iki maddede söz edilmekte ve II. Katerina'nın kendisine ait olan "Senatoya Ferman" adlı kısa bir mektup bulunmaktadır. Bk. Бецкой, Устав Воспитания., 6-33. [Betskoy, İmparatoriçe II. Katerina'nın, 6-33.].

53 Бецкой, Устав Воспитания., 14-15. [Betskoy, İmparatoriçe II. Katerina’nın, 14-15.]

54 Tüzükte çalışan sayısı olarak 172 toplamı verilse de tüzükteki bütün çalışanları değerlendirip topladığımızda 178 rakamına ulaştık. 
edenler ise toplantılar esnasında not tutmakla yükümlü sekreter, enstitünün gelir gider işlerinden sorumlu muhasebeci, rahipler, kilise görevlileri, Ortodoks Kilisesi'nde alt düzey din adamları, genç kızların sağlıklarıyla ilgilenen doktor, eczacı, baş aşçı ve yardımcıları, diğer yardımcılar, fırıncı ve yardımcıları, ilk iki yaş grubunun elbiselerinin dikimlerinden sorumlu terzi, atların bakımından sorumlu hizmetliler, çavuş, demirci, marangoz, benna, onbaşı, davulcu, askerler, enstitünün 1sınma sisteminden sorumlu elemanlar ve yardımcıları, genç kızların yemek masalarının düzenlerinden sorumlu hizmetlilerdi. Ancak bu çalışanların yanı sıra enstitünün yöneticisinin ve müdirenin kendine özel hizmetçileri, yiyeceklerden ve içeceklerden sorumlu elemanları vard1. Enstitüye sadece ders vermek için gelen ve sadece derse girip çıkmakla yükümlü olan öğretmenler arasında Rus dili ve yabancı diller, resim, müzik ve şan, coğrafya, tarih ve arma bilimi tarihi, genç kızların yeteneklerini geliştiren mimari sanatını icra eden öğretmenler ve dans eğitmenleri yer almaktadır ${ }^{56}$.

Tablo 1. Smolniy Enstitüsü'nde Sürekli İkamet Eden Çalışanlar

\begin{tabular}{|l|l|l|l|l|l|}
\hline Çalı̧an & Sayısı & Çalışan & Sayısı & Çalışan & Sayısı \\
\hline Müdüre & 1 & Hizmetçi & 14 & Aşçı Yamağı & 2 \\
\hline Mürebbiye & 1 & Başhemşire & 1 & Bulaşıç̧ı & 4 \\
\hline Denetleyici & 4 & Başhemşire Yardımcısı & 5 & Hamamc1 & 3 \\
\hline Sınıf Öğretmeni & 12 & $\begin{array}{l}\text { Hasta Refakatinde Sorumlu } \\
\text { Kadın }\end{array}$ & 3 & Kapıcı (E) & 2 \\
\hline $\begin{array}{l}\text { Okuma Yazma ve Hemşireliği } \\
\text { Öğreten Rahibe }\end{array}$ & 12 & Aşçı 6-12 yaş grupları için) & 2 & & \\
\hline Toplam & & & & & 70 \\
\hline
\end{tabular}

Tablo 2. Smolniy Enstitüsü Dışında İkamet Eden Çalışanlar

\begin{tabular}{|l|l|l|l|l|l|}
\hline Çalışan & Sayısı & Çalışan & Sayısı & Çalışan & Sayısı \\
\hline Sekreter & 1 & Fırıncı & 1 & $\begin{array}{l}\text { Atların bakımından } \\
\text { sorumlu }\end{array}$ & 6 \\
\hline Muhasebeci & 2 & Fırıncı Yamağı & 2 & Demirci & 1 \\
\hline Rahip & 5 & Terzi & 1 & Benna & 1 \\
\hline Kilise Görevlisi & 5 & Yiyecek sorumlusu & 1 & Marangoz & 1 \\
\hline Hekim & 1 & Hizmetçi & 2 & Onbaşı 1 & \\
\hline $\begin{array}{l}\text { Ortdoks Kilisesinde Alt } \\
\text { Düzey Din Adamı }\end{array}$ & 5 & İçecek sorumlusu & 1 & Çavuş & 1 \\
\hline Eczacı & 1 & Hizmetçi (Yöneticiye bağlı) & 1 & Davulcu & 1 \\
\hline Baş Așçı & 1 & $\begin{array}{l}\text { Yemek masalarından } \\
\text { sorumlu hizmetçi }\end{array}$ & 8 & Asker & 25 \\
\hline Aşçı Yamağı & 1 & Isınma sorumlusu & 6 & & \\
\hline Diğer yardımcı & 3 & $\begin{array}{l}\text { Isınma sisteminin } \\
\text { bakımından sorumlu }\end{array}$ & 2 & & \\
\hline Toplam & & & & & \\
\hline
\end{tabular}

56 Бецкой, Устав Воспитания., 20-22. [Betskoy, İmparatoriçe II. Katerina’nın, 20-22.]. 
Tablo 3. Smolniy Enstitüsü'nde Saat Ücretli Çalışanlar

\begin{tabular}{|l|l|l|l|}
\hline Çalışan & Sayısı & Çalışan & Sayıs1 \\
\hline Rus Dili öğretmeni & 2 & Müzik ve Şan Öğretmeni & 2 \\
\hline Yabancı Dil Öğretmeni & 3 & Çalgııılar & 2 \\
\hline Dans Eğitmeni & 2 & $\begin{array}{l}\text { Coğrafya, tarih, arma ve } \\
\text { tarih bilimi öğretmeni }\end{array}$ & 2 \\
\hline Resim Öğretmeni & 3 & Mimari konular öğretmeni & 1 \\
\hline Toplam & & & 17 \\
\hline
\end{tabular}

Enstitünün ilk öğrencileri her ne kadar ailelerinin etkisinden koparılmış olsalar da diş dünya ile olan etkileşimleri bir biçimde devam etmekteydi. Y1lda birkaç kez olmak üzere örneğin, Noel'de, Çarın veya Çariçenin adına belirlenmiş günlerde çeşitli balolar düzenlenirdi. Bu balolara öğrencilerin dışında öğretmenleri ve müdürleri iştirak ederdi. Öğrenciler burada birkaç saat birbirleriyle dans ederdi. Ancak bu esnada gülmek veya görgü kurallarının dışına çıkmak yasaktı. Bazen bu balolara genç kızların akrabaları olan genç delikanlılar da çağrılırdı.

\subsection{Smolniy Enstitüsü’nün Rusya’da Bıraktığı İzler ve Okulun Kapanması Süreci}

İkinci Katerina'nın emri üzerine açılan ve Rus eğitim tarihinde önemli bir yer edinen Smolniy Enstitüsü, Rusya' da kadın eğitiminin gelişmesi için atılmış olan ilk ve önemli adımlardan birisiydi. Ancak Rusya dışında diğer ülkelerde de sadece kadınların eğitim gördüğü bu tür kurumlara rastlamak mümkündü. Örneğin Avrupa'da ilk kadın okulları 16. ve 17.yüzyılda açılmıştır. Bu okulların ortaya çıkış amacı topluma eğitimli bir anne, eş ve hanımefendi kazandırmaktı. Almanya'da ilk kadın eğitim kurumları tam da Almanya'da reformların başladığı an ortaya çıkmıştır. 1555 senesinde Freiburg başta olmakla beraber Almanya'nın diğer şehirlerinde kadınlar için çeşitli kadın okulları açılmıştır ${ }^{57}$. Daha sonra 17.yüzyılda Fransa'nın Saint-Cyr kentinde The Maison Royale de SaintLouis $^{58}$ adında ilk laik kadın okulu açılmıştır. Bu okulun öğrencileri yoksul soylu kız çocukları arasından belirlenirdi. Bu okul bir sonraki yüzyılda açılacak olan diğer kadın eğitim kurumlarına ve en önemlisi Smolniy Enstitüsü'ne örnek olmuştur. Bir diğer Avrupa ülkesi İngiltere'de ise durum biraz daha farklı gelişmişti. İngiltere'de kadın eğitimi 19.yüzyılın ortalarına kadar din adamlarının ve yine onlara bağlı olan hayır kurumlarının ellerinde kalmışt1 ${ }^{59}$.

1764'te açılan Smolniy Enstiüsü 30 Ağustos 1776 senesinde ilk mezunlarını vermiştir. İlk mezunlar 39 genç kızdan oluşmaktaydı. Mezun olan genç kızların çoğu aldıkları eğitim sayesinde enstitüde kalmış; öğretmen ve mürebbiye olarak kurumda çalışmaya başlamıştır. Diğer genç kızlar ise mezun olduktan sonra enstitünün de kurulma amaçlarından biri olan eğitimli bir kadın, iyi bir

57 https://w.histrf.ru/articles/article/show/zhienskoie obrazovaniie, (16.08.2019/13:00).

58 Asıl ismi "Maison Royale de Saint-Louis" olup Fransa'nın ve aynı zamanda Avrupa'nın ilk laik kadın okuludur. Okul Kral XIV. Louis'in eşi Madame de Maintenon'un isteği üzerine 1686 senesinde Paris'e yakın Saint-Cyr kentinde açılmıştır. Burada yoksul soylu kız çocukları devlet hesabına okuyor ve mezun olana dek burs alıyordu. Okul, kiliselerde görülen eğitimden çok daha fazlasını vermekteydi. Madame de Maintenon vefat edene dek açılışından itibaren okulla kendi ilgilenmiş ve okul onun emirleri ve kuralları çerçevesinde yürütülmüştür. 1719 senesinde Maintenon vefat etmiş ve onun vefatından sonra okul yine aynı düzende devam etmiş ancak 1793 senesinde Jakoben Devrimi ile kapanmıştır. Bk. Elizabeth Rapley, "Fenelon Revisited: A Review of Girls' Education in Seventeenth Century France", Histoire Sociale-Social History 20 (40) (1987): 300.

59 А.А.Вахабова, “Женское образование во Франции и России в ХІХ столетии: Сопоставительный”, Internatıonal Journal of Experimental Education 9 (2015): 16. [A. A. Vahabova, "19.Yüzyılda Rusya'da ve Fransa'da Kadın Eğitimi”, International Journal of Experimental Education 9 (2015): 16.] 
anne ve ailesine yararlı birer birey olarak hayatlarına devam etmişlerdir ${ }^{60}$.

Enstitünün eğitimli bir kadın, iyi bir anne, ailesine ve topluma yararlı bir birey olarak Rus kadınlarını yetiştirmeye dönük misyonu kurucusu İkinci Katerina’nın ölümü üzerine değişmiştir. İlk olarak kurumun yönetimini, tüm hayır ve kadın eğitim kurumlarının yöneticisi olan Birinci Pavel ${ }^{61}$ ' in eşi Çariçe Maria Feodorovna ${ }^{62}$ üstlenmiş ve burada 32 sene görev yapmıştır. Maria Feodorovna bu görevi üstlendiği günden itibaren hem öğrencilerin hem de öğretmenlerin hayatlarında pek çok şeyi değiştirmiştir ${ }^{63}$. Örneğin okulun eğitim süresini 12 y1ldan 9'a düşürmüş, okula kabul edilen kız çocuklarının yaşlarını değiştirmiş ve okula daha fazla saat hesabı çalışan öğretmenler almaya başlamıştır. Değişimin en dikkat çeken yönü II. Katerina topluma daha aydın, daha kültürlü ve daha güçlü genç kızlar kazandırmaya çalışırken, Maria Feodorovna nedeni bilinmese de daha dar görüşlü, daha evcimen ve daha zayıf karakterli genç kızların yetiştirilmesine neden olmuştur ${ }^{64}$.

Rusya'da zamanla Smolniy Enstitüsü’nden başka kadınlara eğitim veren kurumlar da kurulmuştur. Bunlardan bazıları şunladır: Aleksandrov Adına Kadın Enstitüsü, Maria Adına Kadın Enstitüsü, Kadın Vatanseverlik Enstitüsü. Bu kurumlarda öğrenim gören kız çocukları daha çok sıradan, kasabalı, kimsesiz, çiftçi ve askerlerin çocuklarıyd $1^{65}$.

İkinci Katerina'nın Smolniy Enstitüsü’nü açması Rusya'da kadınların eğitimi konusunda atılmış en radikal adımlardan biri olarak tarihe geçmiştir. Enstitü sayesinde kadın eğitimi gelişmiş ve zaman içerisinde başka adlarla kadın eğitim kurumlarının açılmasına bir örnek teşkil etmiştir. Smolniy Enstitüsü bir buçuk asırdan daha fazla bir süre ayakta kalmayı başarmıştır. Ancak 1917'de gerçekleşen Rus Devrimi ile Smolniy Enstitüsü kapatılmıştır. Enstitünün son müdüresi Varvara Golitsyna olmuştur. Devrim döneminde kapatılan bu kurum Ekim ayında Novoçerkassk'a taşınmış ve 1919'da son mezunlarını vermiştir. Böylece enstitü artık tamamen bir tarih olmuştur ${ }^{66}$. Enstitünün mezun ettiği genç kızlardan bazıları daha sonra meşhur olmuştur. Örneğin yazar Moura Budberg, şair Nina Chabias, Rus şair Aleksandr Dobrolyubov’un kız kardeşi Maria Dobrolyubova bir zamanlar Smolniy Enstitüsü’nün mezun ettiği ve meşhur olmuş öğrenciler arasında yer almaktadir ${ }^{67}$.

60 https://histrf.ru/biblioteka/b/kak-v-rossii-poiavilis-institutki, (13.08.2019/12:00).

61 I. Pavel, II. Katerina'nın 1 Ekim 1754 tarihinde Rusya'da dünyaya gelmiş olan oğludur. Annesinin hükümdarlığı sırasında yine annesi tarafından devlet işlerinden uzak tutulmuştur. Ancak 1796 senesinde Çar olmuş, ilk olarak işe II. Katerina’nın yönetim şeklini değiştirmekle başlamıştır. Çar, dönemin tüm özel matbaalarını kapattırmış, eğitim almak için yurtdışına gidişleri yasaklamıştır ve Rus ordusunda baş veren düzensizliğini ortadan kaldırmıştır. I. Pavel 24 Mart 1801 senesinde vefat etmiştir. Bk. Марцева, “Из Истории” 10-11. [Martseva, “Rus Devleti'nin”, 10-11.]

62 I. Pavel'in eşi olan Maria Feoderovna 1759 senesinde Polonya'da dünyaya gelmiştir. Eşi I. Pavel tahta çıktığı günden itibaren Rusya’daki kadın eğitim kurumlarının, kimsesizler evinin ve çeşitli hayır kurumlarının yöneticiliğini yapmıştır. Hayırsever bir kadın olan Maria Feoderovna hayatını kız çocuklarının eğitimine ve yardıma muhtaç kimseler için adamıştır. Feoderovna 1828 senesinde Rusya'da vefat etmiştir. Bk. Г. Л. Микиртичан, "Вклад императрицы Марии Федоровны в организацию помощи детям", Вопросы современной педиатрии 12(3) (2013): 115-122. [G. L. Mikirtiçan, "İmparatoriçe Maria Feoderovna’nın Çocuklara Yardım Komitesine Olan Katkısı", Modern Pediatri Sorulart Dergisi, 12 (3), 2013: 115-122.]

63 Мордвинова, “Смольный институт”, 256. [Mordinova, “İmparatoriçe II. Katerina”, 256.]

64 https://www.culture.ru/materials/211612/istoriya-smolnogo-instituta, (14.08.2019/15:15).

65 Гуркина, История Образования, 21. [Gurkina, Rusya'nın $X-X X$., 21.]

https://w.histrf.ru/articles/article/show/smolnyi institut blagorodnykh dievits, (15.08.2019/19:00).

67 https://www.culture.ru/materials/211612/istoriya-smolnogo-instituta, (14.08.2019/15:00). 
Smolniy Enstitüsü’nün erkek egemen bir çağda bir Rus Çariçesi tarafından kadını eğitim yaşamına katma bakımından başarılı bir deneme olduğu düşünülebilir. Ancak bu girişimin daha da önemli bir hedefi kızlarla erkeklerin aynı ortamda karma bir eğitim görmesiydi. Ne var ki Rusya'da, kızlarla erkeklerin bir arada devam ettiği karma bir eğitime Smolniy Enstitüsü'nün açılmasından nerdeyse bir asır sonra, ancak 1861 senesinde geçilebilmiştir. Ne var ki, o tarihlerde bile okullardaki kız çocuklarının sayısı erkeklere oranla oldukça sınırlı kalmıştır. Kadın eğitim reformunda gerçekleşen bu gibi değişiklere karşı olan muhafazakâr aileler karma eğitimi kabullenmek konusunda ciddi bir direniş sergilemişlerdir. Muhafazakar Rus aileler eski sistemin daha güvenilir olduğunu savunmuş ve yalnız kadınlara eğitim veren okulların devam etmesini talep etmişlerdir. Bu nedenle okullardaki cinsiyet ayrımı yavaş yavaş ortadan kalkmaya başlamış olsa bile Rusya'da çeşitli kadın eğitim kurumları kurulmaya devam etmiştir ${ }^{68}$.

İkinci Katerina aydınlanma çağının aydın despotlarından birisiydi. 1764 yılında Avrupa'dan satın aldığı tabloları sergilemek üzere St. Petersburg'da Küçük Hermitaj Müzesini, daha sonra Büyük Hermitaj Müzeleri'ni inşa ettirmişti. Kadınların eğitimine de eğilen İkinci Katerina 1764'te Smolniy Enstitüsü'nü kurmuştur. Sonraki yıllarda bu enstitünün mezunlarının Rusya'nın soylu ve zengin ailelerine birer mürebbiye olarak girmeleri ve çocukların eğitimlerini ve düşünce şekillerini biçimlendirmeleri nedeniyle bu enstitü, Rusya'nın iktidar sınıfına etki etmiştir ${ }^{69}$.

\section{Sonuç ve Değerlendirme}

İkinci Katerina 1764 yılında Smolniy Kız Enstitüsü’nü, resmi adıyla Soylu Genç (Bekar) Kızları Yetiştirme Ensitüsü'nü, kurmuştur. Enstitünün adı, St. Petersburg'daki Neva Nehri’nin sol yakasındaki Smolniy Manastırı'ndaki yerleşkesinden gelmektedir. Fransa'da kızlar için kurulmuş bir yatılı okul olan Saint-Cyr'den ilham alınarak kurulan Smolniy, Katerina'nın kültürlü, çalışkan ve sadık bir nesil yetiştirmek için yürürlüğe koyduğu eğitim planının bir parçasıydı.

Katerina'nın bu reform için görevlendirdiği İvan Betskoy, tıpkı onu bu göreve getiren Çariçe gibi, Aydınlanma filozoflarının görüşlerinden yoğun bir şekilde istifade eden bir isimdi. Bu bakımdan, Betskoy'un Smolniy için benimsediği pedagojik çerçeve John Locke ve Jean-Jacques Rousseau'nun fikirlerine dayanarak oluşturulmuştu ve ahlaki eğitim ile çevresel faktörlere göre tasarlanmıştı. Kızlar Smolniy'de, beş yaşından on sekiz yaşına kadar, ev ziyareti yapmadan, sıkı bir eğitim ve gözetim altında yetiştirildiler. Sanat Akademisi gibi tüm erkek okullarında olduğu gibi, Smolniy'de güzel sanatlar, özellikle dans ve drama alanlarında dersler verildi. Müfredat içerisinde, ayrıca, okuma-yazma, yabancı diller, fizik, kimya, coğrafya, matematik, tarih, Ortodoksluk, iğne işi ve ev ekonomisi gibi dersler de bulunmaktaydı. Voltaire, müfredatının zenginliği bakımından Smolniy'i Saint-Cyr'den daha üstün saymıştı. Tüccarların ve askerlerin kızları için daha dar kapsamlı bir müfredatlı bölüm kuruluşundan bir sene sonra okula eklendi.

Katerina, Smolniy'de halka açık sınavlar ve oyun performansları düzenledi ve en sevdiği öğrencileri Yaz Bahçeleri’ndeki gezinti yerlerinde ağırladı. Bu okul ve etkinlikleriyle ilgili portreleri çizmesi için ressam Dmitry Levitsky görevlendirildi. Smolniy'den mezun olanlar, görgü ve yetenekleriyle biliniyordu ve her şeyden evvel oldukça arzulanan gelin adayları olarak kabul edildiler. Bazıları okulda öğretmen olarak kaldı ve birkaç tanesi saray nedimeliğine kadar terfi etti.

\footnotetext{
68 Ю. С. Елонова, "История Женского Образования в России, Как Отражение Культуры Общества", Педагогические Науки 8 (2011): 14. [YU. S. Yelonova, "Kültürel Hayatın Yansıması Olan Rusya'daki Kadın Eğitiminin Tarihi”, Eğitim Bilimleri Dergisi 8 (2011): 14.] 
Katerina'nın ulusal bir okul sistemi kurma komisyonunu yöneten Peter Zavadovsky, 1783'te Smolny’nin fỉili başı olarak Betskoy’un yerine geçti. Fransızcayı, okulun eğitim dili olarak Rusça'nın yerine koydu ve kızların gelecekteki rollerini iyi birer eş ve anne olarak belirleyen yeni bir müfredat çıkard1.

1796'da Katerina'nın ölümünün ardından, Maria Fedorovna enstitüyle bizzat ilgilendi ve Smolniy'nin gelecekte rotasını çizecek düzenlemeleri gerçekleştirdi. Bu dönemde, okula kabul yaşı beşten sekize çıkarıldı ve ev ziyareti yasağı gevşetildi.

19. yüzyıl boyunca Smolniy, Rus kızları için en seçkin eğitim kurumu olarak ününü korumuştur. Adı, bazen mezunlarının Smolniy dışındaki yaşam için saf ve kötü hazırlanmış olduğu düşünüldüğü halde, yüksek kültürel standartlar, görgü ve letafet ile eşanlamlı olarak anıldı. Rus edebiyatında Smolniy’ye yapılan 18. ve 19. yüzyıllara ait birçok referans, okulun kültürel önemine işaret etmektedir.

Vladimir Lenin ve Bolşevikler Ekim 1917'de Smolniy Enstitüsü'nü ele geçirdiler ve buray1 Mart 1918'e kadar karargâh olarak kullandılar. O tarihten bu yana Smolniy Yerleşkesi kamu hizmetlerinde kullanılmaya devam etti. Bugün St. Petersburg Valiliği’ne ev sahipliği yapan yerleşkede enstitünün geçmişini yaşatmak üzere birkaç oda müze olarak korunmaktadır.

\section{KAYNAKÇA}

\section{1-Rusça Kaynaklar}

Бецкой, И.И. Устав Воспитания Двухсот Благородных Девиц, Учрежденного Императрицей Екатериной II. СПБ: 1764. [Betskoy, İ. İ. İmparatoriçe II. Katerina'nın Kurduğu 200 Soylu Genç Kızlar Talim ve Terbiye Okulunun Tüzüğ̈̈. St. Petersburg: 1764.]

Васильевна, Б.О. “Гимназическое Образование В России В XVIII Веке”. Молодой учёный 27 (131) (2016): 646-647. [Vasilyevna, B. O. “18. Yüzy1lda Rusya’da Lise Eğitimi”. Genç Bilim Adamı Dergisi 27 (131) (2016): 646-647.]

Вахабова, А.А. “Женское образование во Франции и России в XIX столетии: Сопоставительный”. Internatıonal Journal of Experimental Educatıon 9 (2015): 16-24. [Vahabova, A. A. “19. Yüzyılda Rusya'da ve Fransa'da Kadın Eğitimi”, Internatıonal Journal of Experimental Education 9 (2015): 16-24.]

Гуркина, Н.К. История образования в России ( $X-X X$ века). СПБ: СПБГУАП, 2001. [Gurkina, N. K. Rusya'nın X-XX. Yüzyıl Eğitim Tarihi, St. Petersburg: St. Petersburg Üniversitesi Havacılık Araçları Yayın Evi, 2001.

Елонова, Ю.С. “История Женского Образования в России, Как Отражение Культуры Общества". Педагогические Науки 8 (2011): 11-15. [Yelonova, YU. S. "Kültürel Hayatın Yansıması Olan Rusya'daki Kadın Eğitiminin Tarihi”. Eğitim Bilimleri Dergisi 8 (2011): 11-15.]

Зуев, Г. И. Историческая хроника Морского корпуса 1701-1925. Москва: ЗАО Центрполиграф ООО «МиМ-Дельта», 2005. [Zuyev, G. İ. 1701-1925 Yullarında Deniz Piyadeleri Tarihi Kitabı, Moskova: Mim Delta Yayını, 2005.]

Каган, М. С. “О Роли Екатерины Великой В Истории России”. Екатерина Великая: Эпоха Российской Истории, 73-75. Санкт-Петербург: Спб Нц, 1996. [Kagan, M. S. "Yüсе Katerina'nın Rus Tarihindeki Rolü’. Rus Tarihinde Büyük Katerina Devri Uluslararası Sempozyumu Bildirileri Kitabı içinde, 73-75. St. Petersburg: St. Petersburg Bilim Merkezi Yayını, 1996.] 
Ключевский, В. О. Сочинения В 9 Томах-Том 5. Москва: Мысль, 1989. [Klyuçevskiy, V. O. 9 Ciltte Eserler Kitabı-5.Cilt. Moskova: Düşünce Yayını,1989.

Колосова, Е. М. “Он Жил Для Всех. К 305-Летию Со Дня Рождения И.И.Бецкого”. Вестник Герценовского университета 1 (63) (2009): 72-74. [Kolosova, Ye. M. “O Herkes İçin Yaşad1. İvan Betskoy'un 305. Yaş Gününe İthafen”. Rusya Herzen Üniversitesi Haberleri Dergisi 1 (63): 72-74.

Лимонова, Ю. А. Россия $X V$-XVII вв. Глазами Иностранцев. Ленинград: Лениздат, 1986. [Limonova, Yu. A.Yabanciların Gözünde 15.-18.yüzyılda Rusya Kitabı. St. Petersburg: Lenizdat Yayını, 1986.]

Лотман, Ю. М. Беседы $о$ русской культуре.Быт $u$ традиции русского дворянства (XVIIIначало XIX века). Санкт-Петербург: Искусство-СПБ, 1994. [Lotman, Yu. M. Rus Kültürü Hakkında Sohbetler ve Rus Soyluların Gelenekleri (18. Yüzyılın Başları-19. Yüzyıl). St. Petersburg: Sanat-St. Petersburg Yayını, 1994.]

Марцева, Л. М. “Из Истории Государства Российского. Династия Романовых Справочно-Хронологический Материал По Истории России”. Национальные Приоритеты России 3 (25) (2017): 3-14. [Martseva, L. M. "Rus Devleti'nin Tarihinden Rus Tarihine Göre Romanov Hanedanlığının Kronolojisi”, Rusya'nın Geleneksel Portreleri Dergisi 3 (25) (2017): 3-14.]

Микешин, М. И. “Просвещенная Монархия Как Идеология”. Екатерина Великая: Эпоха Российской Истории, 77-80. Санкт-Петербург: Спб Нц, 1996. [Mikeşin, M. İ. “İdeoloji Olarak Aydınlanmış Monarşi”. Rus Tarihinde Büyük Katerina Devri Uluslararası Sempozyumu Bildirileri Kitabı içinde, 77-80. St. Petersburg: St. Petersburg Bilim Merkezi Yayını, 1996.]

Микиртичан, Г.Л. “Вклад императрицы Марии Федоровны в организацию помощи детям”. Вопросы современной педиатрии 12(3) (2013): 115-122. [Mikirtiçan, G. L. “İmparatoriçe Maria Feoderovna’nın Çocuklara Yardım Komitesine Olan Katkısı". Modern Pediatri Soruları Dergisi 12 (2013): 115-122.]

Мордвинова, 3. Е. “Смольный институт в эпоху императрицы Екатерины II (17641796)". Вопр. Образования 3 (2007): 255-276. [Mordinova, Z. YE. "İmparatoriçe II. Katerina Döneminde Smolniy Enstitüsü (1764-1769)”. Eğitim Sorunları Dergisi 3 (2007): 255-276.

Моряков, В. И. “Екатерина І1 И Русские Просветители О Воспитании «Истинного Сына Отечества»”, Екатерина Великая: Эпоха Российской Истории, 80-84. Санкт-Петербург: Спб Нц, 1996. [Moryakov, V. İ. "II. Katerina ve Rus Eğitim Aydınları-Gerçek Anavatan Evladı", Rus Tarihinde Büyük Katerina Devri Uluslararası Sempozyumu Bildirileri Kitabı içinde, 80-84. St. Petersburg: St. Petersburg Bilim Merkezi Yayın1, 1996.]

Моряков, В. И. “Екатерина І1 И Русские Просветители О Воспитании «Истинного Сына Отечества»”. Екатерина Великая: Эпоха Российской Истории, 80-84. Санкт-Петербург: Спб Нц, 1996. [Moryakov, V. İ. "II. Katerina ve Rus Eğitim Aydınları-Gerçek Anavatan Evladı". Rus Tarihinde Büyük Katerina Devri Uluslararası Sempozyumu Bildirileri Kitabı içinde, 80-84. St. Petersburg: St. Petersburg Bilim Merkezi Yayını, 1996.]

Пекарский, П. П. Наука И Литература При Петре Великом T. 1. СПБ: Товарищества “Общественная польза", 1862. [Pekarskiy, P. P. Yüce Petro Döneminde Bilim ve Edebiyat Kitabı I. St. Petersburg: Dostluk Yarı Kamu Yayın1, 1862.]

Петинова, Е. Ф. Во дни Екатерины. СПБ: Книжный Мир, 2002. [Petinova, YЕ. F. 
Katerina Günlerinde. St. Petersburg: Kitap Dünyası Yayını, 2002.]

Поздняков, А. Н. “Институты благородных девиц в системе образования России второй половины XVIII-начала XIX века”. Изв. Сарат. ун-та. Нов. сер. Сер. Философия. Психология. Педагогика 2 (14) (2014): 104-108. [Pozdnyakov, A.N. “18. Yüzyılın İkinci Yarıs1-19. Yüzyılın Başlarında Rusya'nın Eğitim Sisteminde Soylu Genç Kızlar Enstitüsü”, Saratov Üniversitesi Haberler Dergisi 2 (14) (2014): 104-108.]

Помелов, В. Б. “Смольный Институт Блогадарных Девиц”. Начальная Школа 2 (2015): 84-89. [Pomelov, V. В. “Soylu Genç Kızlar Smolniy Enstitüsü”. İlkokul Dergisi, 2 (2015): 84.89.]

Соловьев, С. М. История России C Древнейших Времен: B 29 T. Москва: ДиректМедиа, 2016. [Solovyev, S. М. Antik Çağlardan Rus Tarihi: 29 Ciltlik Kitap, Moskova: Direkt Media Yayını, 2016.

Стенник, Ю. В. (Спб), “Концепция «Просвещенного Абсолютизма» В Культурной Политике Екатерины I1”. Екатерина Великая: Эпоха Российской Истории, 57-60. СанктПетербург: Спб Нц, 1996. [Stennik, Yu. V. “II. Katerina’nın Kültürel Politikasındaki “Aydınlama Mutlakiyeti” Kavramı”, Rus Tarihinde Büyük Katerina Devri Uluslararası Sempozyumu Bildirileri Kitabı içinde, 57-60. St. Petersburg: St. Petersburg Bilim Merkezi Yayın1, 1996.]

Фоккеродта, И. Г. ve О. Плейер. Россия при Петре Великом, По Рукописному Известию. Москва: Имп. О-ва Истории И Древностей Росс. При Моск. ун-те, 1874. [Fokkerodta, İ. G. Ve O. Pleyer. El Yazmalarına Göre Yüce Petro'nun Egemenliğindeki Rusya Adlı Kitabı. Moskova: Moskova Üniversitesi'ne Bağlı Olan İmparatorluk Topluluğunun Tarihi ve Antik Rusya Adlı Yayın1, 1874.

Юровская, Э. П. “Утопические Черты Организации Императорского Воспитательного Общества Благородных Девиц”. Екатерина Великая: Эпоха Российской Истории, 107-111. Санкт-Петербург: Спб Нц, 1996. [Yurovskaya, E.P. “İmparatorluğun Soylu Genç Kızlarının Talim ve Terbiye Topluluğu” veya "Soylu Genç Kızlar Enstitüsü’nün Ütopik Özellikleri”, Rus Tarihinde Büyük Katerina Devri Uluslararası Sempozyumu Bildirileri Kitabı içinde, 107-111. St. Petersburg: St. Petersburg Bilim Merkezi Yayın1, 1996.]

\section{2-Türkçe ve İngilizce Kaynaklar}

Acar, Kezban. Ortaçă̆'dan Sovyet Rejimine Rusya. İstanbul: İletişim Yayınları, 2009.

Aslan, Mahir. “1783 Kırım’ın Rusya’ya İlhakı Sürecinde İkinci Katerina’nın Yunan Projesi ve Önemi”. Türk Dünyası Araştırmaları 213. (2014): 221-230.

Çevik, Mustafa. “David Hume 'da Din ve Tanrı Anlayışı.” Doktora Tezi, Ankara Üniversitesi Sosyal Bilimler Enstitüsü, 2003.

Defoe, Daniel. Robinson Crusoe. Çev. Akşit Göktürk. İstanbul: Yapı Kredi Yayınları, 2016.

Ergün, Mustafa. "Rus Eğitiminde Batılılaşma Çabaları ve Reformlar”. Kuramsal Eğitimbilim 2 (1) (2009): 31-56.

Günaydın, Hamza ve Burak Coşkun. “İsveç Kralı XII. Charles’ın (Demirbaş Şarl) Osmanlı Devleti'ne İlticası (1709-1714) ve İltica Süresinde Ülkesinde Ombudsman Görevlendirmesine İlişkin Bir Değerlendirme”. Ombudsman Akademik 5 (9) (2018): 15-73.

Hoebel, E. Adamson. "William Robertson: An 18th Century Anthropologist-Hisatorian”, American Anhropologist 62 (4) (1960): 648-655. 
Horn, David Bayne. Great Britain and Europe in the Eighteenth Century. California: Clarendon Press, 1967.

Kurat, Akdes Nimet. Rusya Tarihi Başlangıçtan 1917'ye Kadar. Ankara: Türk Tarih Kurumu Yayın1, 1987.

Kuzucu, Serhat. "II. Katerina Dönemi Osmanl1-Rus İlişkilerinde Kırım”, Türk Dünyası Araştırmaları 185. (2010): 107-118.

Mercan, Mehmet. Katerina Tarihi. Ankara: Karaman Bilim ve Araştırma Merkezi Yayını, 2010 .

Rapley, Elizabeth. 'Fenelon Revisited: A Review of Girls' Education in Seventeenth Century France”, Histoire Sociale-Social History 20 (40) (1987): 299-318.

Saray, Mehmet. Türk-Rus Münasebetlerinin Bir Analizi. İstanbul: Milli Eğitim Bakanlı̆̆1 Yayın1,1998.

Sarıhmetoğlu, Nesrin. "Rusya İmparatorluğu.” Rusya Tarihi içinde, ed. Nadir Devlet ve Nesrin Sarıhmetoğlu, 98-131. Ankara: Anadolu Üniversitesi Yayını, 2013.

Şahin, Zulfiya. “XVIII. Yüzyılın İlk Yarısında Rusya'nın Kültürel Gelişimi ve Batıya Uyum Çabaları”. Ankara Üniversitesi Sosyal Bilimler Dergisi 5 (2) (2014): 171-191.

Şıhverdiyev, Kadir. “II. Katherina (1729-1796) Döneminde Rusya Müslümanları.” Yüksek Lisans Tezi, Erciyes Üniversitesi Sosyal Bilimler Enstitüsü, 2006.

Uçar, Fuat. "II. Katerina (1762-1796)". Uzman Araştırmacı Ĕgitim Programı Makaleler-I içinde, ed. Turgay Anar, 53-80. İstanbul: İstanbul Bilimler Akademisi Vakfı Yayın, 2017.

Upton, A. F. Charles XI and Swedish Absolutism. New York: Camrdige University Press, 1998.

\section{3-Internet Kaynakları}

https://www.liveinternet.ru/users/ninapr/post428879026/

http://peshegrad.ru/articles/gimnaziya-pastora-glyuka

https://travelkap.ru/statial/gljuk/index.html

https://wol.jw.org/ru/wol/d/r2/lp-u/2007444

https://www.moya-planeta.ru/travel/view/pravila_zhizni_kisejnoj_baryshni_30959/

$\underline{\text { https://w.histrf.ru/articles/article/show/zhienskoie obrazovaniie }}$

https://histrf.ru/biblioteka/b/kak-v-rossii-poiavilis-institutki

https://www.culture.ru/materials/211612/istoriya-smolnogo-instituta

https://w.histrf.ru/articles/article/show/smolnyi institut blagorodnykh dievits 


\section{EKLER}

\section{Smolniy Enstitüsü'ne Ait Bazı Görseller}

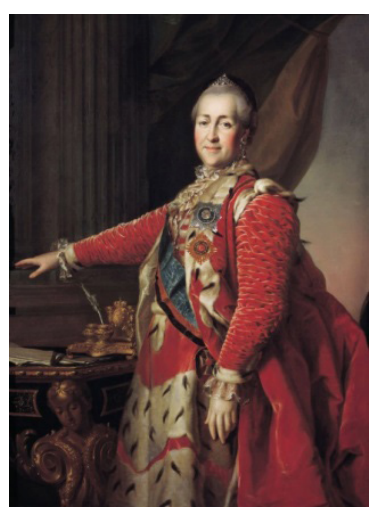

Resim 1. II. Katerina Tablosu (1782)

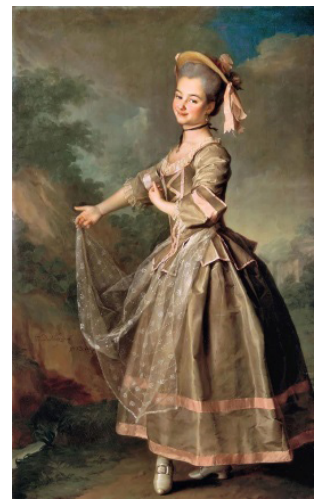

Resim 3. Smolniy Enstitüsünde Sahnelenen Bir Tiyatro Sahnesi Sırasında Özel Kostümüyle Dans Eden Bir Genç Kız Tasviri

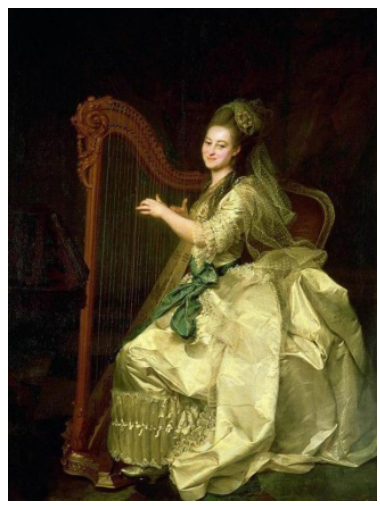

Resim 5. Genç Kız Arp Çalarken

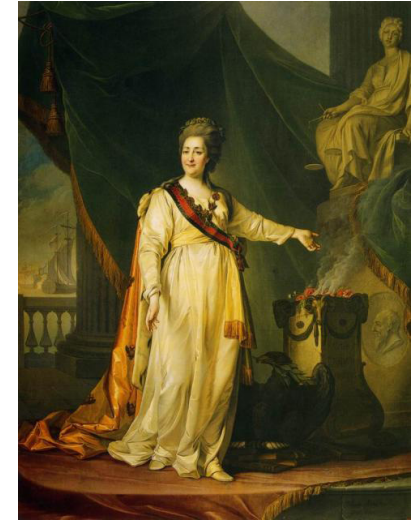

Resim 2. II. Katerina Tablosu. (1783)

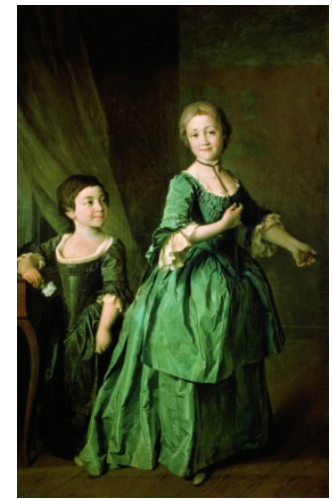

Resim 4. 9-12 Yaş Grubuna Ait Kız Çocukların Tasviri

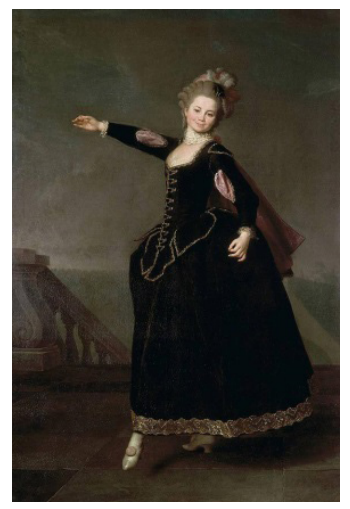

Resim 6. "Hizmetçi Hanımefendi" Adlı Tiyatro Esnasında Dans Eden Bir Genç Kız 


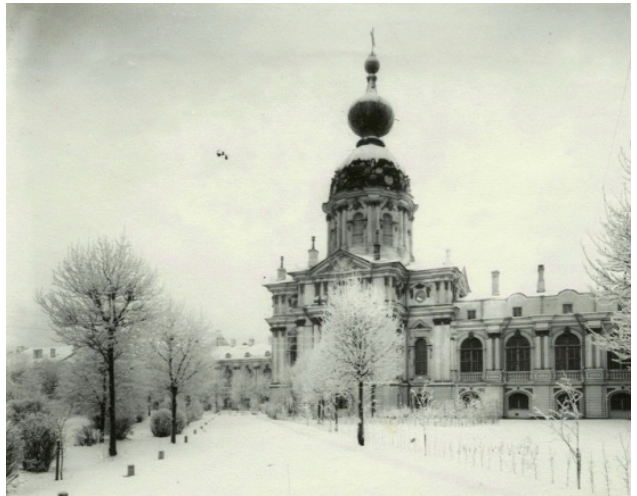

Resim 7. Smolniy Enstitüsü Kilisesi

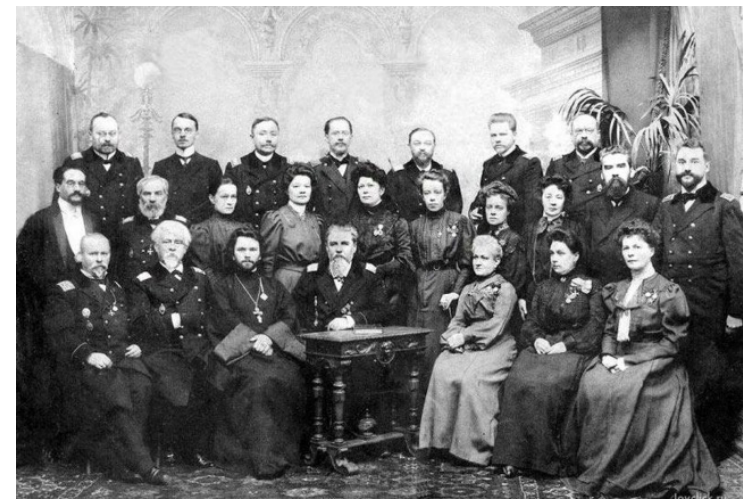

Resim 9. Smolniy Enstitüsüdeki Öğretmenleri

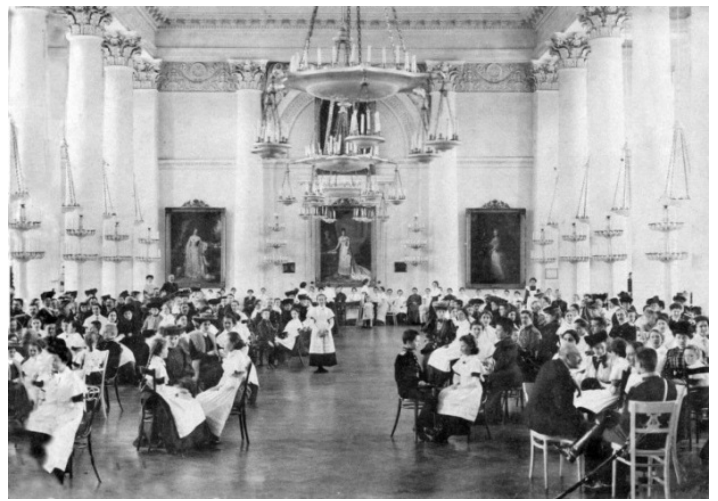

Resim 11. Smolniy Enstitüsü Görgü Kuralları Sinavından Bir Kare

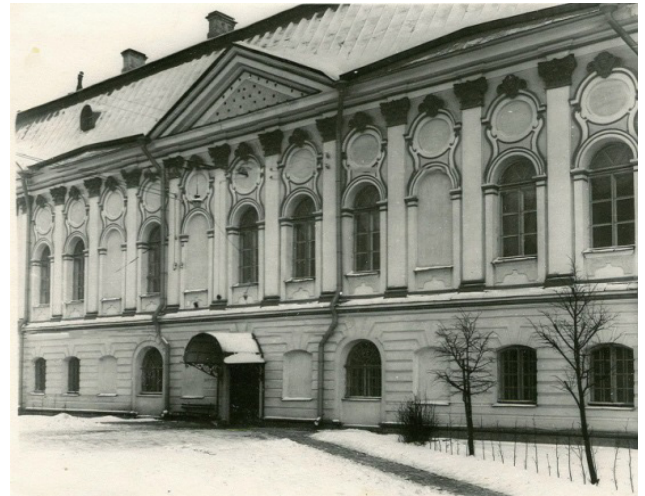

Resim 8. Smolniy Enstitüsü Öğrencilerinin Kaldığı Bina

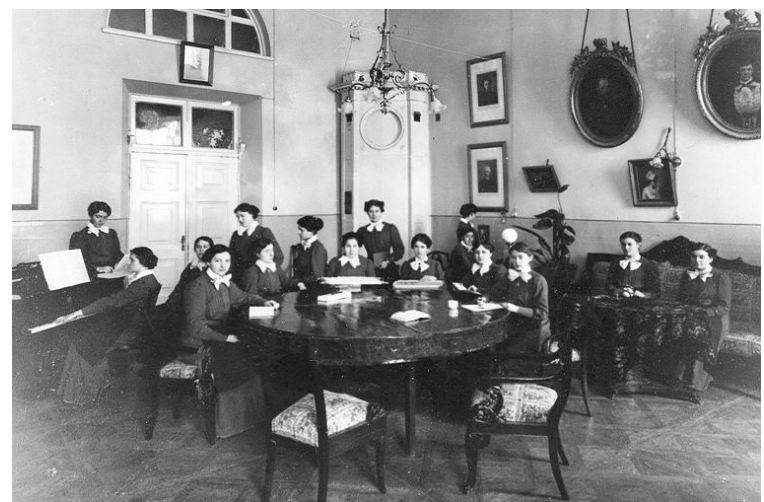

Resim 10. Smolniy Enstitüsü Misafir Salonunda Okuma ve Dikiş ile Meşgul Bir Grup Genç Kız

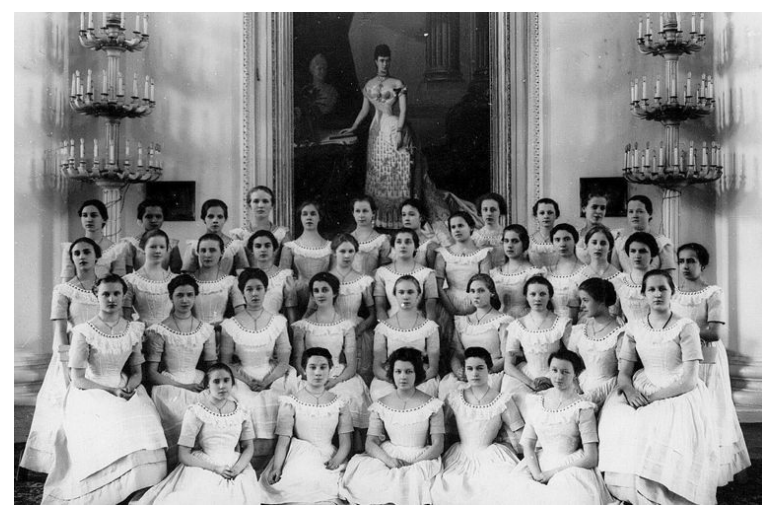

Resim 12. Smolniy Enstitüsü Balo Hatırası 


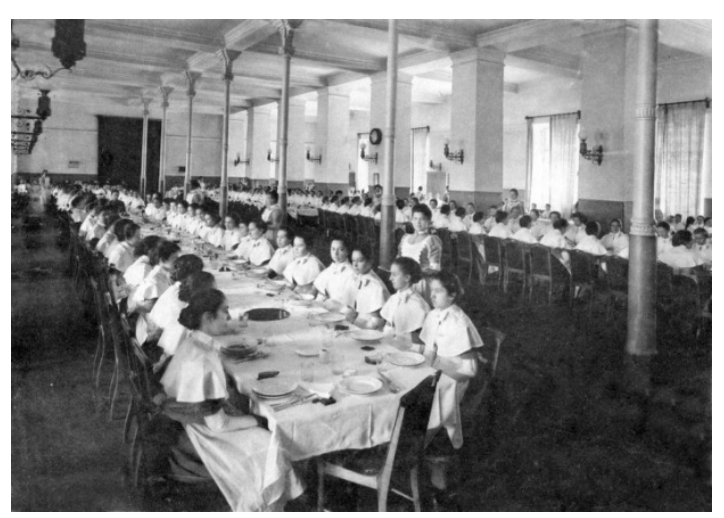

Resim 13. Genç Kızlar Yemek Odasındayken-1889 Yılına Ait Olan Mezuniyet Albümünden

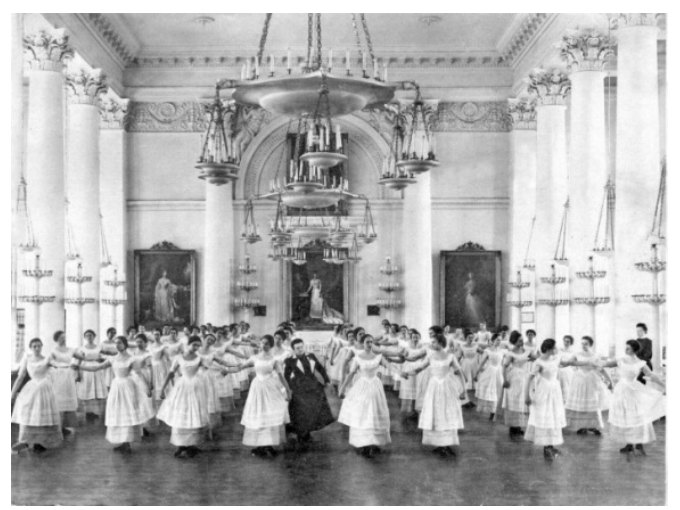

Resim 15. Dans Dersinden Bir Kare (1901)

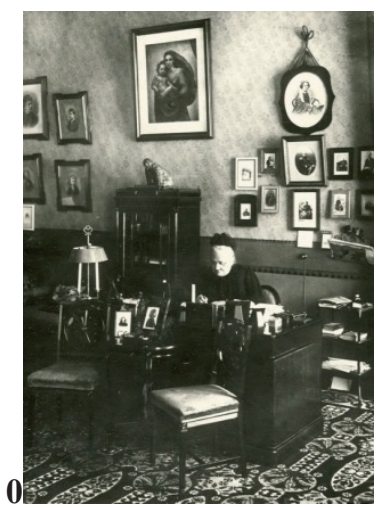

Resim 17. Enstitü Müdirelerinden "Ye. A. Liven" Masa Başındayken

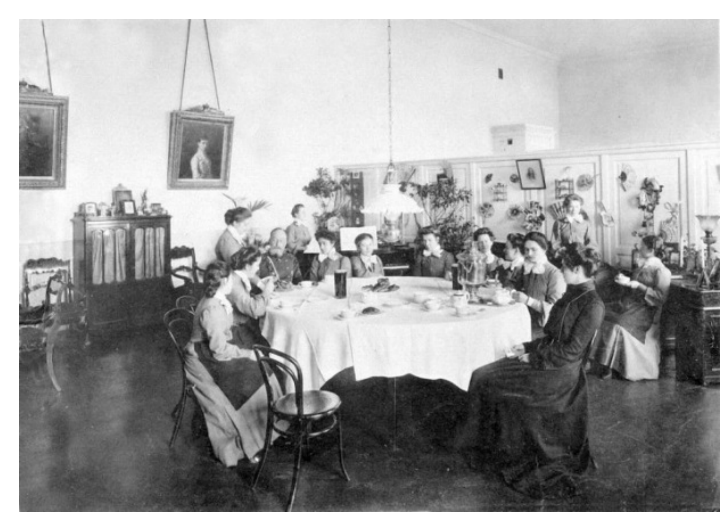

Resim 14. Smolniy Enstitüsü-Misafirler İle Çay Saati

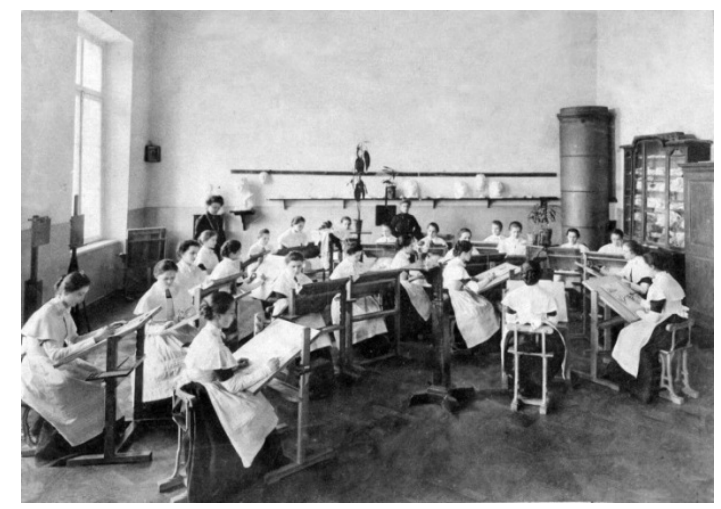

Resim 16. Resim Dersinden-1889 Yılına Ait Mezuniyet Albümünden

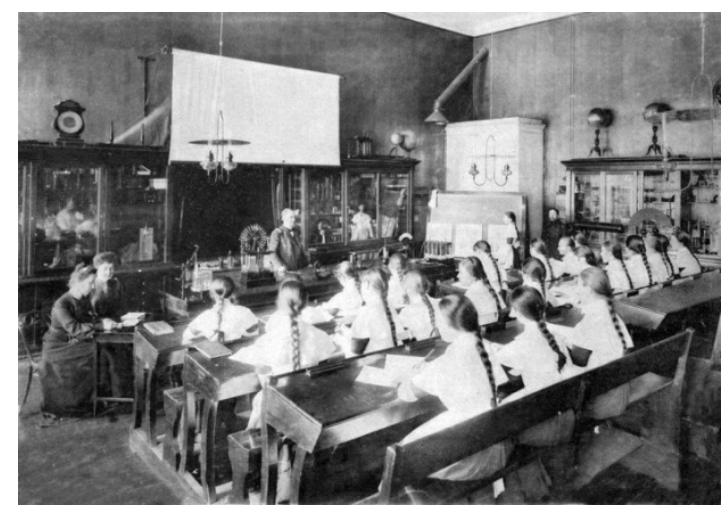

Resim 18. EI İşi Dersinden 


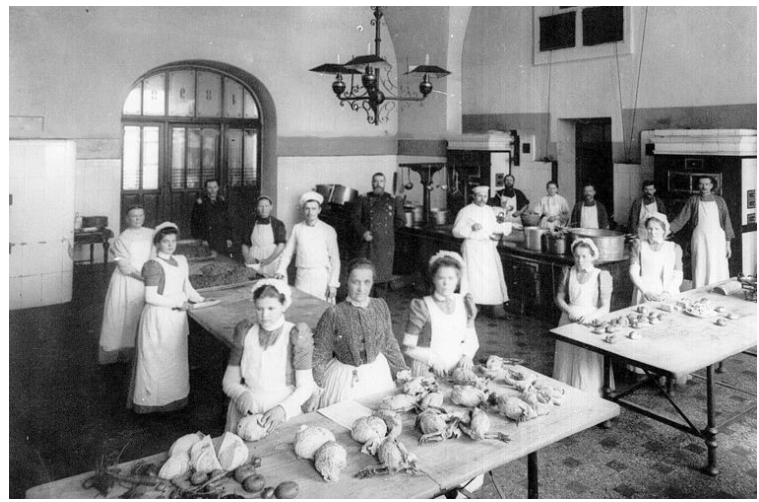

Resim 19.Yemek Hazırlamakta Olan Bir Grup Hizmetli

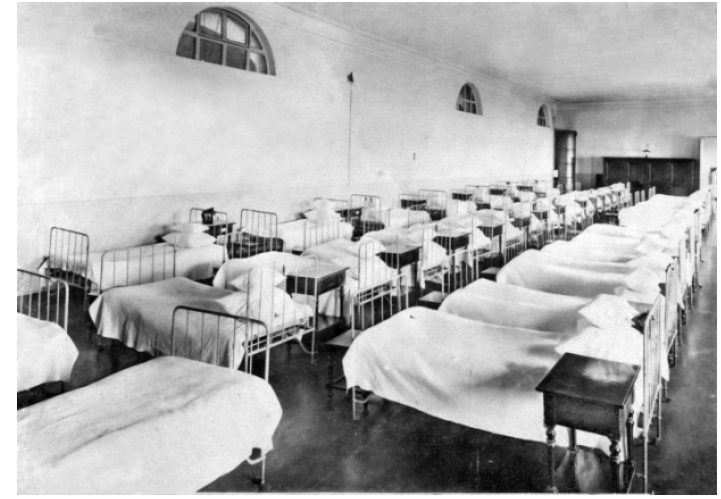

Resim 20 Yatakhane.

Smolniy Enstitüsü öğrencilerine ait yağlıboya resimler 1772-76 yılları arasında Rus Çariçe II. Katerina'nın emri üzerine ressam Dmitriy Levitskiy tarafından resmedilmiştir. (https://smolny. livejournal.com/4417.html - LIVEJOURNAL Adlı İnternet Sitesinden alınmıştır.)

Siyah-beyaz fotoğraflar https://kulturologia.ru/blogs/040515/24370/ - Kültürel Bilim Adlı İnternet Sitesinden alınmıştır.

II. Katerina Tablosu (1782) muzei-mira.com/kartini_russkih_hudojnikov/2682-portretekateriny-ii-dmitrij-grigorevich-levickij-opisanie.html-Dünya Müzeleri Adlı İnternet Sitesinden alınmıştır.

II. Katerina Tablosu (1783) http://www.virtualrm.spb.ru/ru/node/8043 - Rus Müzesi Adlı İnternet Sitesinden alınmıştır. 